\title{
Paleomagnetic evidence of localized vertical axis rotation during Neogene extension, Sierra San Fermín, northeastern Baja California, Mexico
}

\author{
Claudia J. Lewis ${ }^{1}$ \\ Department of Earth and Planetary Sciences, Harvard University, Cambridge, Massachusetts
}

Joann M. Stock

Seismological Laboratory, California Institute of Technology, Pasadena

\begin{abstract}
Paleomagnetic data from Sierra San Fermín in the Gulf of California Extensional Province indicate that localized clockwise rotations about vertical axes occurred during Pliocene through Recent extension and dextral shear. Relative declination discordances in upper Miocene and Pliocene ash flow tuffs indicate a net clockwise rotation of $30^{\circ} \pm 16^{\circ}$. Clockwise rotation between 12.5 and $6 \mathrm{Ma}$ is statistically insignificant $\left(11^{\circ} \pm 17^{\circ}\right)$. Structural observations and geochronological data suggest that rotations in this area began post- $6 \mathrm{Ma}$, comprising uniformsense block rotations (oblique divergence) associated with extension and dextral slip in the northwest striking boundary between the Pacific and North American plates. Northeast striking sinistral-slip faults and north striking normal faults accommodate distributed dextral shear in this area, allowing fault blocks to rotate in a clockwise sense. A model for oblique divergence predicts $-21 \mathrm{~km}$ of shear in the direction of relative plate motion and $\sim 20 \%(\sim 7 \mathrm{~km})$ ENE directed extension, perpendicular to the Main Gulf Escarpment. A broad region of northeastern Baja California may have undergone similar distributed shear. Two possible dynamic models may explain this shear. In one model, rotation accumulates above a deep, subhorizontal, basal shear zone. Rotating blocks may extend downward to a detachment beneath the extensional province, either a low-angle eastward continuation of the San Pedro Mártir fault or to a basal shear surface on top of a subducted remnant of the Farallon plate. Alternatively, distributed dextral shear may be the surface manifestation of a deep vertical shear zone linking transform faults in the northern gulf with dextral transpeninsular faults. In either case, shear may have transferred northward onto faults west of the San Andreas fault, contributing to late Miocene to Recent clockwise rotation of the Western Transverse Ranges. This shear is not accounted for in the $300 \mathrm{~km}$ of dextral slip computed from cross-gulf geologic tie points.
\end{abstract}

\section{Introduction}

Vertical axis rotations are increasingly recognized as a fundamental component of continental deformation, particularly in areas where shear is distributed in transpressional or transtensional environments. Block rotations have occurred at many Neogene strike-slip plate boundaries, including northern Israel [Ron et al., 1984; Nur et al., 1989], the Anatolian Trough-Aegean Sea area [Kissel et al., 1989], and the Alpine fault zone in New Zealand [Walcott, 1984, 1989]. Various areas along the boundary between the Pacific and North American plates have undergone rotation in Neogene time as well [Johnson et al., 1983; Kamerling and Luyendyk, 1985; Luyendyk et al., 1985; Weldon, 1986; Burbank and Whistler, 1987; Ross et al., 1989; MacFadden et al., 1990; Luyendyk, 1991].

Active tectonism at these plate margins is characterized by considerable nonrigid deformation. Where there is a com-

\footnotetext{
${ }^{T}$ Now at Los Alamos National Laboratory, Los Alamos, New Mexico

Copyright 1998 by the American Geophysical Union.

Paper number 97JB02673.

0148-0227/98/97JB-02673\$09.00
}

ponent of shortening or extension, simple shear is taken up by a combination of strike-slip and dip-slip faults. Experimental models of oblique rifting show that the relative amounts of extension and shear depend on the acute angle between the rift trend and the displacement direction (azimuth of plate motion along plate margins) [Withjack and Jamison, 1986; Tron and Brun, 1991]. Where this angle exceeds $30-45^{\circ}$, normal faults are common and tend to dominate the topography.

Two-dimensional block models of distributed deformation suggest a way in which strike-slip and dip-slip deformation and paleomagnetic rotations may be kinematically connected and how fault movement and block rotation within a zone of distributed deformation may be related to the relative motion of the tectonic plates that bound the zone [McKenzie and Jackson, 1983, 1986]. The oblique divergence model predicts extension perpendicular to the boundaries of the deforming zone and strike-slip on faults conjugate to the shear direction. In many areas of southern California, for example, rotating blocks are bounded by sinistral or sinistral oblique slip faults conjugate to the principal dextral faults of the plate boundary [e.g., Bogen and Seeber, 1986; Luyendyk et al., 1985].

In northeastern Baja California (Figure 1), the transtensional plate tectonic setting and prevalence of sinistral strikeslip faults, in addition to the dominant system of normal faults, led us to investigate the possibility that part of the Neogene 


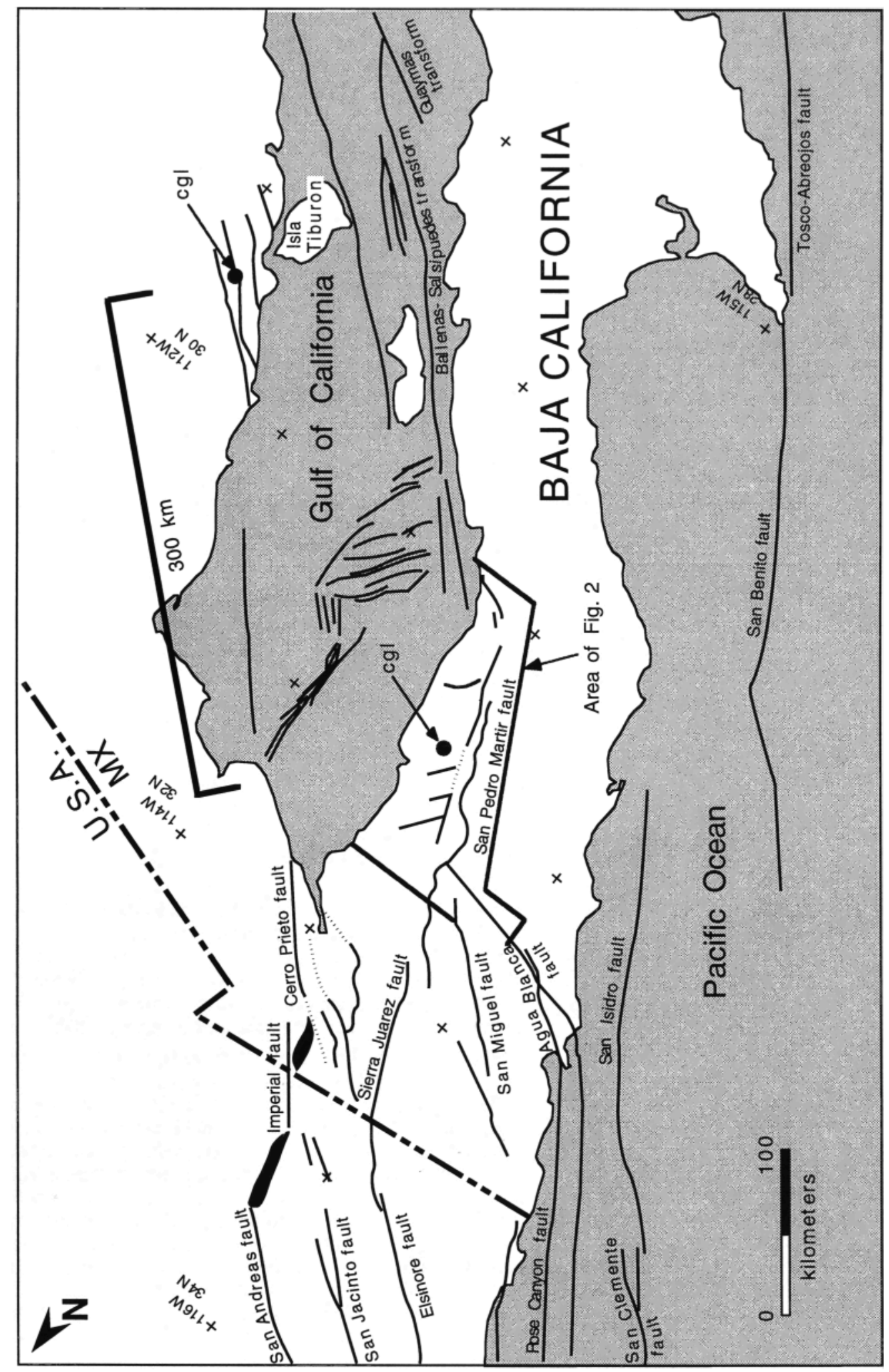

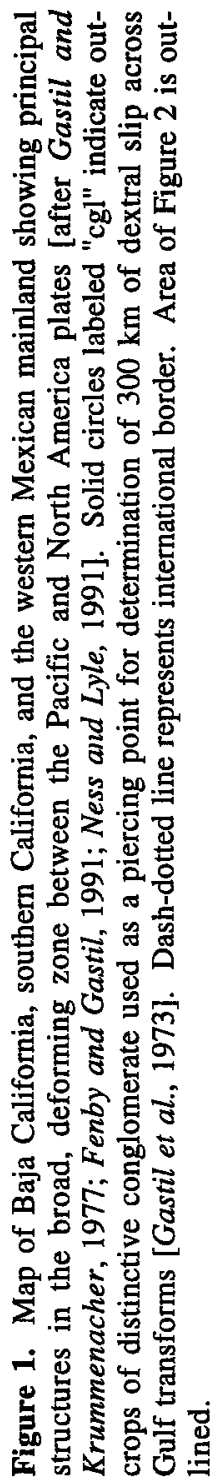


deformation in this area was accommodated by rotations about vertical axes. Our paleomagnetic data demonstrate that clockwise rotation of structural blocks, in addition to extensional and strike-slip faulting, accounts for significant late Miocene to Recent deformation in this area. Rigid body rotation can contribute an important component of relative plate displacement through time [e.g., Hornafius et al., 1986; Luyendyk, 1990; Dickinson, 1996] and may allow extension independent of that produced by pure dip-slip motion. Our data suggest that this is the case for northeastern Baja California. Thus adding magnitudes of slip on major faults will underestimate extension across the Gulf Extensional Province, and the relative dextral displacement of the Pacific and North American plates.

\section{Geologic Setting}

The Sierra San Fermin and Sierra San Felipe, in northeastern Baja California, Mexico, lie in the Gulf of California Extensional Province, a region of late Miocene through Recent crustal extension and shear at the Pacific-North American plate boundary (Figure 1). The western limit of extension is the Main Gulf Escarpment. The principal fault of the escarpment at this latitude is the east dipping San Pedro Mártir fault (Figure 1) [Hamilton, 1971; Brown, 1978; Slyker, 1974]. Numerous northeast striking sinistral faults and northeast striking extensional basins have been mapped east of the San Pedro Mártir fault, including a late Miocene bathyal-depth marine basin [Hamilton, 1971; Andersen, 1973; Boehm, 1984; Bryant, 1986; Stock et al., 1996]. The Sierra San Fermin and southern Sierra San Felipe are two of the many, roughly northeast striking, parallel ranges in this area (Figure 2).

The Sierra San Fermín is in large part the hanging wall of the east dipping Sierra San Felipe fault, one of the principal structures of the extensional province (Figures 2 and 3) [Stock and Hodges, 1990]. The eastern escarpment of the Sierra San Felipe formed post- $6 \mathrm{Ma}$, but the fault has been inactive in Quaternary time and possibly Pliocene time as well [Stock et al., 1991; Stock, 1993; Lewis, 1994]. Detailed mapping and kinematic indicators indicate that at least since latest Miocene time, the area has undergone dextral shear accommodated by north striking normal faults and northeast striking sinistralslip faults [Lewis, 1994; Lewis and Stock, 1998].

\section{Field and Laboratory Procedures}

Regionally extensive ash flow tuffs, with distinctive yet consistent vectors of magnetization, are common in the northern Puertecitos Volcanic Province (Figure 2) and provide markers for structural studies. The most useful tuffs for this study, largely distal parts of individual cooling units, are the 12.5 Ma Tuff of San Felipe (Tmsf [Stock et al., 1997]), the 6 Ma Tmr3a, Tmr3b, and Tmr4 (Tertiary Miocene rhyolites, in chronological order), and the $3 \mathrm{Ma}$ Tpet (Tertiary Pliocene Tuffs of Mesa El Tábano; Figure 4). An angular discordance between the Tuff of San Felipe and overlying $6 \mathrm{Ma}$ tuffs indicates the onset of normal faulting in this area between 12.5 and $6 \mathrm{Ma}$ (age quoted here is older than originally cited because more recent data show Tmsf is $\sim 12.5$ Ma [Stock and Hodges, 1990; Lewis, 1996; Nagy, 1997]). The tuffs which comprise the 3 Ma Tpet are less deformed than the late Miocene (12.5-6 Ma) ignimbrites [Stock et al., 1991]. Nonetheless, Tpet is affected by normal and strike-slip faulting, which continues today.

Ash flow tuffs, both welded and nonwelded, are noted for the stability of their magnetic remanence [e.g., Best et al., 1973; Gromme et al., 1972; Reynolds, 1977; Weiss et al., 1989]. Their magnetic properties have been used successfully both to correlate ash flow tuffs [e.g., McIntosh, 1991] and to measure rotations about vertical axes [e.g., Hudson and Geissman, 1987; Wells and Hillhouse, 1989]. Because ash flow tuffs cool quickly relative to secular variation of the Earth's magnetic field [Riehle, 1973; Byrd et al., 1994], all inclinations from the same cooling unit should agree within uncertainties, whereas declination anomalies likely arise from tectonic rotations. Declinations from individual cooling units can thus be compared directly to determine relative amounts of vertical axis block rotations. In practice, many factors may complicate this simple pattern [Hudson et al., 1994].

A total of 208 oriented cores for paleomagnetic analysis were drilled from 32 sites at 10 localities (Figure 3). Each site represents an area of several tens of square meters of an individual cooling unit with stable remanent magnetization. Samples were oriented to an accuracy of $\pm 1^{\circ}$ using a Brunton (magnetic) compass and, when lighting conditions allowed, a Sun compass.

Paleohorizontal indicators were carefully assessed at each site. Where possible, attitudes of interbedded sedimentary strata or compaction foliation in ash flow tuffs were measured. At two localities, we determined attitudes from structure contour maps on the basal surface of tuffs ( $n$-point solutions); these measurements represent attitudes averaged over distances greater than a kilometer. Because tilting occurred between deposition of some ash flows, different structural corrections were typically required for sites at each locality.

All demagnetizations and measurements were done at the California Institute of Technology in a shielded mu-metal room with ambient field less than $10 \mathrm{nT}$. Remanent magnetization directions and intensities were measured using a computerinterfaced cryogenic superconducting quantum interference device (SQUID) magnetometer with a background noise level of $5 \times 10^{-12} \mathrm{~A} \mathrm{~m}^{2}$.

We performed demagnetization and rock magnetic experiments on pilot specimens to determine the stability of the natural remanent magnetization (NRM), and which phases carry it [Lewis, 1994]. We subjected one group of pilot samples to alternating field (AF) demagnetization to peak fields of $80 \mathrm{mT}$ and another to thermal demagnetization to temperatures above $700^{\circ} \mathrm{C}$ to determine an appropriate demagnetization strategy. $\mathrm{AF}$ and thermal demagnetization paths (fit by the least squares analysis of Kirschvink [1980]) indicate that the NRM of most samples is characterized by one well-grouped component of magnetization carried by two mineral phases: (1) a moderate unblocking temperature $\left(<580^{\circ} \mathrm{C}\right)$, moderate coercivity (median destructive induction of 10 to $100 \mathrm{mT}$ ) remanence characteristic of fine-grained magnetite (or low-Ti titanomagnetite), and (2) a parallel-directed or scattered, higher unblocking temperature $\left(>580^{\circ} \mathrm{C}\right.$ ), high-coercivity (MDI $>100 \mathrm{mT}$ ) remanence (Figure 5) characteristic of maghemite and/or hematite microcrystals that grew from the quenched matrix glass [e.g., McIntosh, 1991; Rosenbaum, 1993]. In addition, nearly all samples show a small viscous magnetic component (VRM) which was removed by low-intensity alternating fields $(<20 \mathrm{mT}$; Figure 5$)$. The remanence carried by magnetite generally represents about three-quarters of the total vector $J_{0}$ intensity [Lewis, 1994]. Acquisition and demagnetization of isothermal remanent magnetization (IRM) and anhysteretic remanent magnetization (ARM) indicate that the magnetic remanence is carried dominantly by fine-grained particles of magnetite of single domain or pseudo-single domain size [Lewis, 1994]. In some vapor-phase crystallized or devitrified, densely welded tuffs, the high-temperature remanence represents as much as two-thirds of the NRM intensity.

Progressive demagnetization of the remaining specimens entailed an initial AF demagnetization in several steps up to 15 to $20 \mathrm{mT}$ to remove the VRM. This treatment was followed by progressive AF demagnetization to $80 \mathrm{mT}$ to remove magneti- 


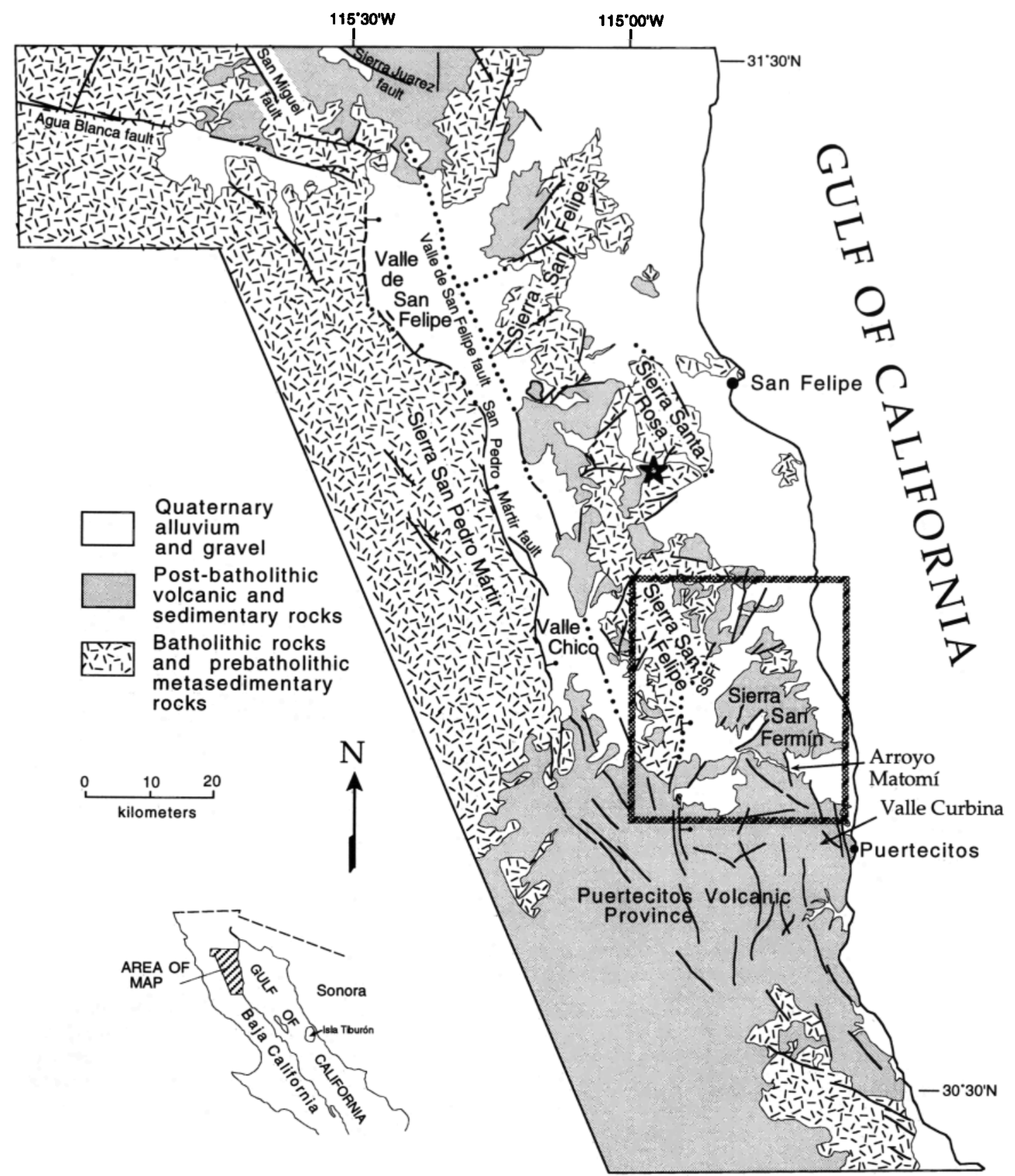

Figure 2. Regional geologic map of part of northeastern Baja California (modified from Gastil et al. [1975]). The western boundary of the zone of extension is the Main Gulf Escarpment. The San Pedro Mártir fault is the principal fault of the escarpment at this latitude. SSSf is Sierra San Felipe fault. Area of Figure 3 is outlined. Star is an outcrop of conglomerate used in determination of $300 \mathrm{~km}$ dextral offset across the gulf [Gastil et al., 1973].

zation held by magnetite. Finally, some samples were thermally demagnetized over temperatures between $600^{\circ}$ and $730^{\circ} \mathrm{C}$ to remove the high-coercivity remanence presumably carried by maghemite and/or hematite. The directions of characteristic components of the NRM were then found for visually determined segments using the least squares methods of principal component analysis [Kirschvink, 1980]. We report results from all sites in Table 1 . A total of 15 individual samples from seven sites exhibited unstable demagnetization behavior (MAD $>10^{\circ}$ ) and were rejected. Site means with $\alpha_{95}>$ $15^{\circ}$ (three localities) are reported in Table 1 but not averaged into the unit means. We exclude the site mean for the tuff of San Felipe from locality SFH because its inclination is significantly different from other Tmsf site means; it may be a different tuff. We exclude the site mean for the $6 \mathrm{Ma}$ Tmr4 from Mesa Cuadrada due to inadequate structural control; the outcrop is not in place.

We include the $3 \mathrm{Ma}$ "Tpet" site mean from locality SFG, although the correlation with Tpet in Arroyo Matomi has not been proved beyond a doubt. In outcrop appearance, lithologic characteristics, and stratigraphic position, these tuffs appear to be Tuffs of Mesa El Tábano. However, the ${ }^{40} \mathrm{Ar} /{ }^{39} \mathrm{Ar}$ isotopic 


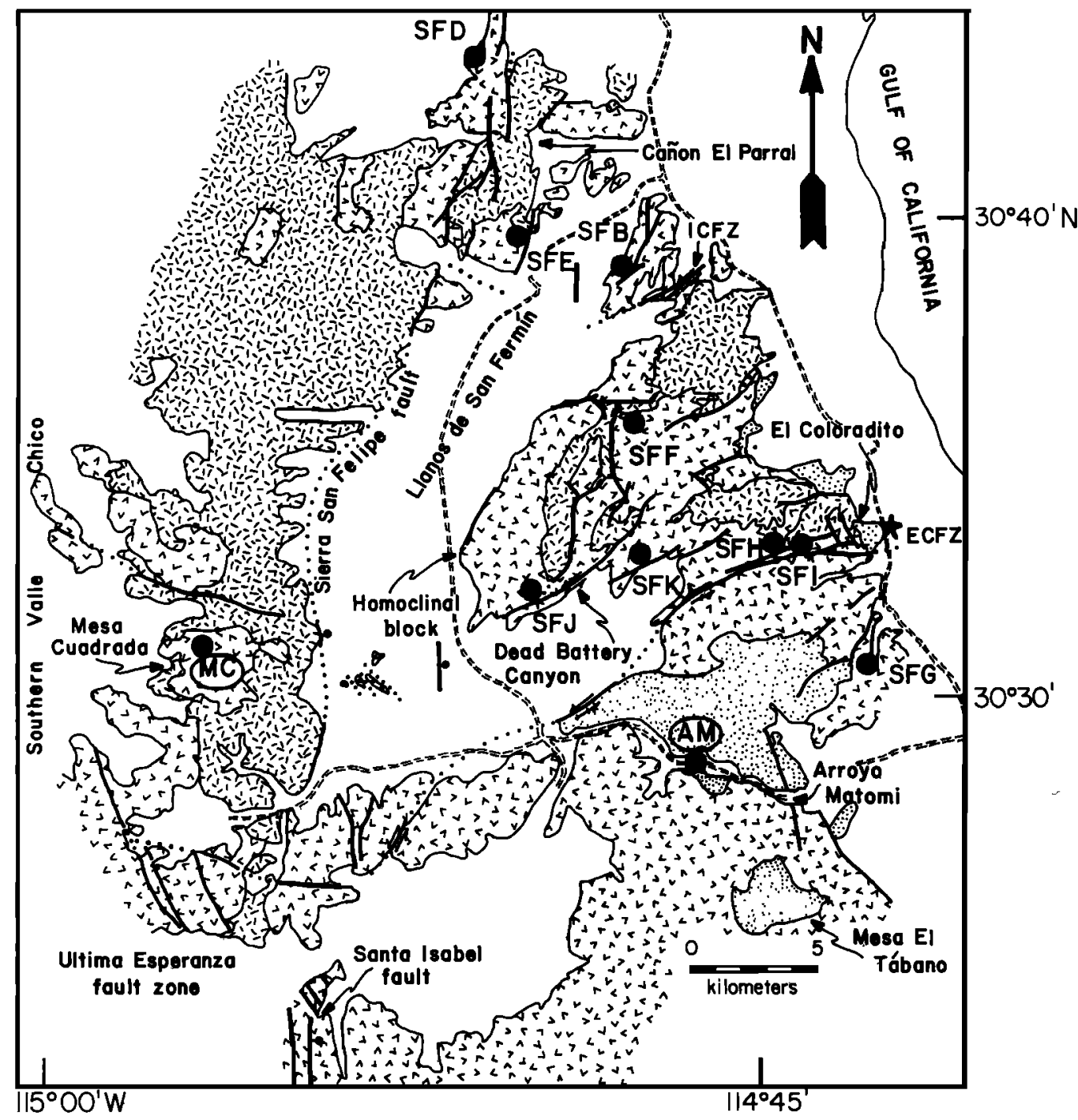

Figure 3. Generalized geologic map showing sampling localities and principal geographic features discussed in text. Stratigraphic groups are as in Figure 4. Solid circles mark sampling localities (three-letter designations with "SF" for "San Fermín" followed by a letter from A to K; MC, Mesa Cuadrada; AM, Arroyo Matomí). Local reference localities are circled. Strangway et al. [1971] sites are indicated by the star. Arroyo Matomí locality (AM) and Valle Curbina locality (not shown; see Figure 2) were sampled and analyzed by Melbourne et al. [1993]. Heavy, solid lines indicate faults (ball and bar on downthrown side). Faults are ECFZ, El Coloradito fault zone; and ICFZ, Ironwood Canyon fault zone. Mapping from Mesa Cuadrada and Ultima Esperanza fault zone is from Stock and Hodges [1990]. Mapping from Arroyo Matomí and Mesa El Tábano is from Stock et al. [1991]. Mapping of rest of area is from Lewis [1994].

dateage obtained for one of these tuffs was older than expected (5.6 $\pm 0.2 \mathrm{Ma}$ versus an expected age of $-3 \mathrm{Ma}$ [Lewis, 1996]). Because the ${ }^{40} \mathrm{Ar} /{ }^{39} \mathrm{Ar}$ age was obtained from plagioclase and radiogenic yields were poor, we have more confidence in the field relations than in the geochronology.

\section{Paleomagnetic Evidence of Vertical Axis Rotations}

\subsection{Reference Localities}

We are principally interested in establishing whether relative block rotations have occurred within this part of the Gulf Extensional Province, indicating a significant component of rotational strain in addition to extension and shear. We compare declinations of site means from localities within the area of sinistral faulting to declinations from localities outside the zone of sinistral faulting, enabling us to establish whether relative rotations have occurred and delimit, in part, the boundaries of the rotating zone. We do not average data together from zones of diverse structural character for comparison to the stable reference pole for North America because doing so would obscure relative rotations of structural blocks. The results we obtain from direct comparison of declinations are not biased appreciably by whole plate tectonic movements because paleomagnetically significant Neogene rotation, and translation, of the entire Baja California peninsula is ruled out by both geologic constraints and previous paleomagnetic studies [Hagstrum et al., 1987; Hausback, 1988]. Spreading in the gulf caused clockwise rotation $\left(<3^{\circ}\right)$ and northward translation $\left(\sim 3^{\circ}\right.$ of latitude) of the entire peninsula [Stock and Hodges, 1989], but neither is resolvable within the error limits of paleomagnetic data. 


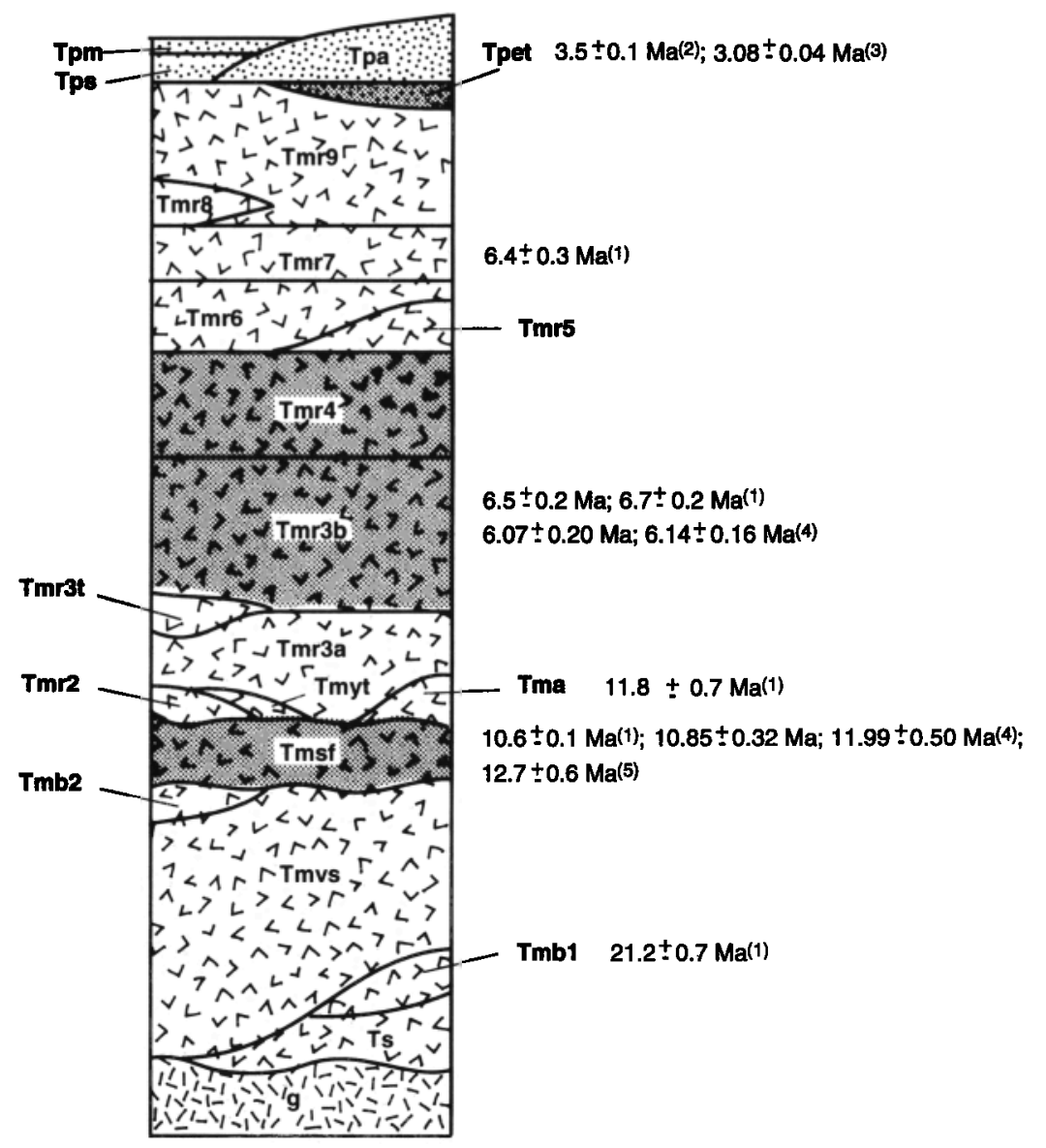

Figure 4. Composite stratigraphic column showing principal mapping units as follows (grouped according to lithologic type): batholithic and prebatholithic rocks (g); sedimentary rocks (Ts, Tpm, Tps); predominantly andesitic volcaniclastic rocks (Tmvs); basalts (Tmb1, Tmb2); rhyolite flows (Tmr2, Tmr9); rhyolitic ash flow tuffs (Tmsf, Tmyt, Tmr3a, Tmr3b, Tmr4, Tmr5, Tmr6, Tmr7, Tmr8, Tpet); and basaltic andesites (Tma, Tpa). Most important units for paleomagnetic analysis are stippled gray. Sources of ${ }^{40} \mathrm{Ar} /{ }^{39} \mathrm{Ar}$ geochronologic data: (1) Lewis [1996]; (2) Martín Barajas et al. [1995]; (3) Martín Barajas and Stock [1993]; (4) Stock [1989]; (5) Nagy [1997].

To evaluate possible vertical axis rotation of the Sierra San Fermin with respect to its footwall, the southern Sierra San Felipe, we compare site means from three tuffs with site means from Mesa Cuadrada (chosen as a reference because of its location in the footwall of the Sierra San Felipe fault and outside the area of sinistral faulting; Figure 3). Likewise, we compare site means in $3 \mathrm{Ma}$ Tpet to a unit mean (averaging data from two cooling units whose vectors of magnetization are indistinguishable within uncertainties) from Arroyo Matomí and Valle Curbina (Figures 2 and 3 ) to evaluate vertical axis rotations across the northern limit of a proposed dextral accommodation zone [Dokka and Merriam, 1982; Stock and Hodges, 1990]. In this case, the reference locality was chosen because of its location within the accommodation zone and outside the area of sinistral faulting. There is no one suitable reference locality for all the pyroclastic deposits due to their geographic distribution.

\subsection{Nontectonic Causes of Variation in Magnetization Directions}

We interpret declination differences between sites with caution because errors associated with site means incorporate only statistical uncertainty, with the result that apparent interblock rotations may not be significant. The uncertainty associated with a single site mean does not include error from tilt corrections, systematic errors in sample orientations or measurements, or spatial variability and random or nonrandom noise at the scale of a regionally extensive ash flow tuff and is thus likely to be an underestimate of the total uncertainty.

Differences in inclination between sites may also have a nontectonic origin. Inclination anomalies may result from inclination bias in welded ignimbrites, which can be produced by subblocking temperature compaction and welding, causing inclinations to vary with density of welding [e.g., Rosenbaum, 1986], or variation in cooling time across the ignimbrite sheet, incorporating appreciable secular variation of the magnetic field [e.g., Wells and Hillhouse, 1989]. In this study, we noticed no systematic variations in inclination, but these variations may be difficult to detect without dense vertical sampling.

Errors in tilt correction are likely to be our greatest source of uncertainty. Tilt corrections based only on measured eutaxitic foliations in ash flow tuffs may be in error if foliation was not originally horizontal. Tilt corrections are generally made assuming that structural tilt resulted from rotation about a horizontal axis, the line of strike of bedding. If the tilt of a fault block resulted from rotation about an inclined axis, or successive rotations about distinct horizontal axes, apparent declination anomalies may result [McDonald, 1980]. Generally, this is only a significant problem for steeply tilted 

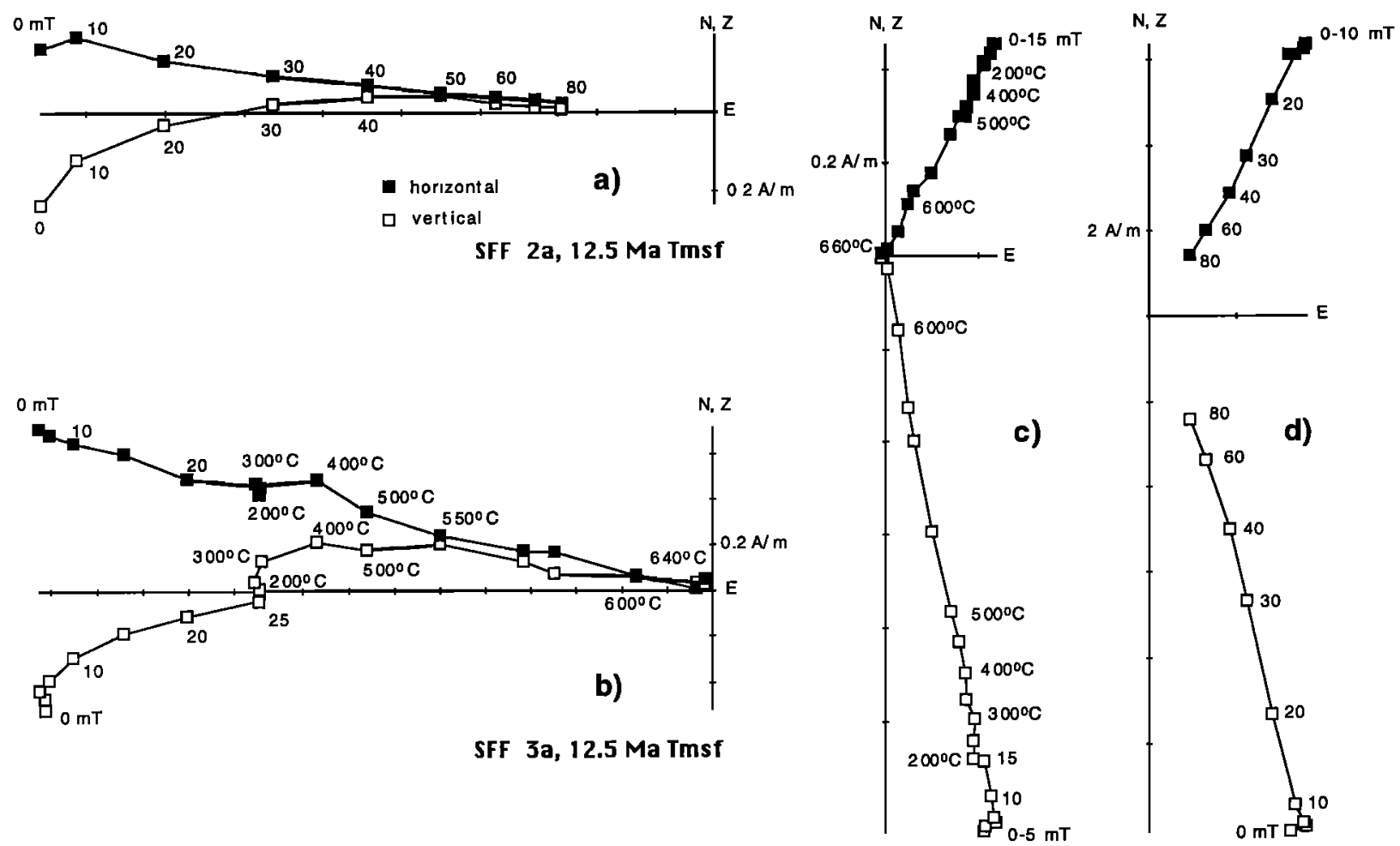

SFB 12c, 6 Ma Imr3b

SFB 12b, 6 Ma Tmr3b

Figure 5. Representative orthogonal diagrams of tilt-corrected, progressive AF and thermal demagnetization results demonstrating straightforward isolation of characteristic remanent magnetization (ChRM). Orthogonal demagnetization diagrams show the endpoint of the magnetization vector simultaneously plotted onto the horizontal (N-S, E-W) plane (solid squares) and the vertical (up-down) plane (open squares) for each demagnetization step [Zijderveld, 1967]. Peak demagnetizing inductions (in $\mathrm{mT}$ or ${ }^{\circ} \mathrm{C}$ ) are given beside projections onto vertical and horizontal planes. The intensity of magnetization remaining in the sample (in $\mathrm{A} / \mathrm{m}$ ) is given along one of the axes. (a) and (b) Devitrified, densely welded interior of Tmsf (12.5 Ma), showing distinctive low-inclination, reversed polarity vector of magnetization. (c) and (d) Basal brown glass of partially welded Tmr3b ( $\sim 6 \mathrm{Ma})$, showing small component of VRM, removed by weak field AF demagnetization, principal magnetite TRM, removed by progressive AF demagnetization to $80 \mathrm{mT}$ or progressive thermal demagnetization to approximately $580^{\circ} \mathrm{C}$, and parallel, high-coercivity maghemite component (high-temperature deuteric $\mathrm{CRM})$ removed by high-temperature $\left(>600^{\circ} \mathrm{C}\right)$ thermal demagnetization.

rocks. Testing our data for rotations about inclined axes using the method of Chan [1988] shows that the observed declination anomalies cannot be explained by a single rotation about an inclined axis or by folding about a processing fold axis.

\subsection{Comparisons Between Localities}

We first look for relative rotations between fault blocks in the study area (excluding the reference localities) and then compare site means to the reference localities. In general, we note close clustering of site means, within specific units, from the $12.5,6$, and $3 \mathrm{Ma}$ tuffs, suggesting that no significant relative rotation has occurred between the different localities (Figure 6). The principal exceptions are (1) the Tmsf site mean from site SFF, which is $\sim 20^{\circ}$ clockwise relative to other Tmsf site means in the Sierra San Fermín and (2) the declinations of Tmr3a and Tmr4 from locality SFB, which are both more northerly than those from other localities (Figure 7). It may be unreasonable to assume that Tmsf at SFF was deposited parallel to bedding in underlying sedimentary rocks. Alternatively, the block that contains SFF may have rotated clockwise relative to adjacent blocks. However, the $6 \mathrm{Ma}$ Tmr3b site mean from SFF is consistent with the other Tmr3b means. In the second case, the tuff of San Felipe declination from SFB is the same, within uncertainties, as the other Tmsf declinations in the Sierra San Fermin, although $6 \mathrm{Ma}$ ash flow tuffs from locality SFB appear to have rotated less than other localities in the Sierra San Fermín. Flattening at locality SFB is anomalous but not systematic for all deposits (except $\mathrm{Tmr} 3 \mathrm{~b}$ ), suggesting that structural corrections there may be in error. Using attitudes determined from map patterns instead of foliations does not eliminate anomalous flattening at this locality.

Site means from three tuffs (6 Ma Tmr3a, Tmr4, and Tmr6) are somewhat scattered, but uncertainties in tilt corrections may contribute to the dispersion. Small changes in dip, for example, have a marked effect on the Tmr4 declination from locality SFF. The variation in Tmr4 declinations has no consistent relation to thickness changes in Tmr4; localities SFI and SFK are located in the thickest parts of the tuff (up to 50 $\mathrm{m}$ ), whereas Tmr4 is $<2 \mathrm{~m}$ thick at locality SFB.

There is an apparent systematic southward increase, within the Sierra San Fermín, in the amount of clockwise deflection in all $6 \mathrm{Ma}$ tuffs except Tmr3b (Table 1). However, there is no such systematic trend in site means from the 12.5 Ma tuff of San Felipe. Comparison of site means from the Sierra San Fermín and Cañon El Parral area of the southern Sierra San Felipe thus shows no consistent pattern of rotations between 


\begin{tabular}{|c|c|c|c|c|c|c|}
\hline क्ष & 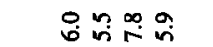 & $\ddot{0} \stackrel{\infty}{\subseteq} \stackrel{\infty}{\infty}$ & 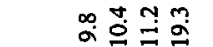 & 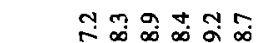 & 会立会会 & P \\
\hline \& & 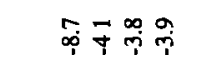 & $\vartheta \stackrel{7}{9}$ & 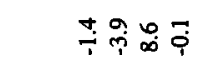 & 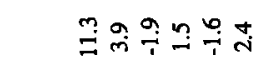 & 会会会会是 & $\theta$ \\
\hline$\approx$ & 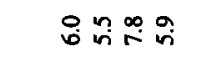 & 象象 & 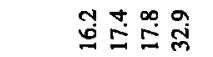 & 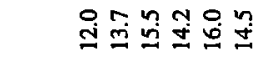 & 是是是是是县 & 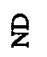 \\
\hline$\approx$ & 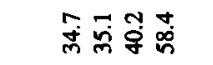 & 官管棉 & 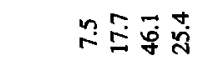 & 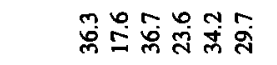 & 是会会是会 & \\
\hline$\approx$ & 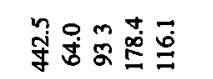 & $\begin{array}{l}\sigma \infty \\
\infty \\
\infty\end{array}$ & 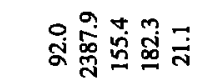 & 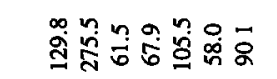 & 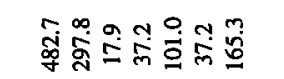 & 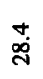 \\
\hline 80 & テ约の゙す & そ苛苛 & 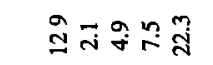 & 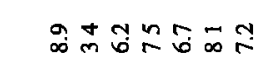 & 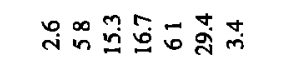 & 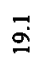 \\
\hline & 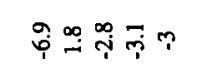 & $\stackrel{ }{\rightrightarrows} \stackrel{0}{\circ}$ & 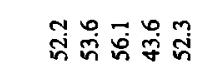 & 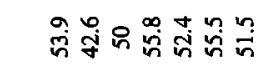 & 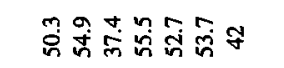 & 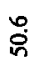 \\
\hline 이 & 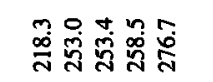 & 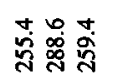 & 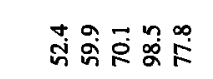 & 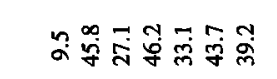 & 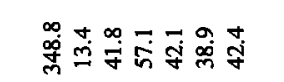 & 8 \\
\hline & 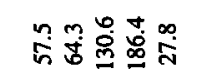 & 章品え & 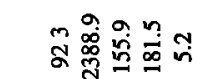 & 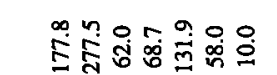 & 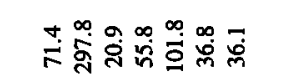 & $\overrightarrow{0}$ \\
\hline & 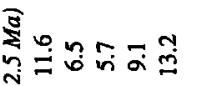 & 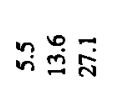 & 急实 & 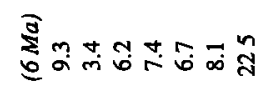 & 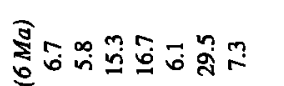 & $\frac{q}{q}$ \\
\hline & 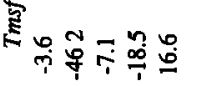 & 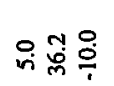 & 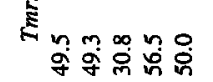 & 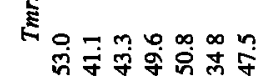 & 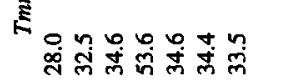 & \\
\hline 0 & 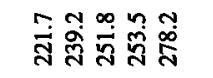 & 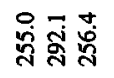 & 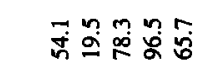 & 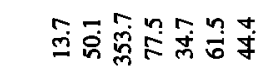 & 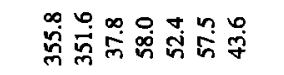 & : \\
\hline$z_{z}^{\circ}$ & 号器下品品 & 号军的 & 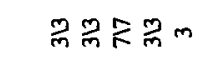 & 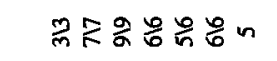 & 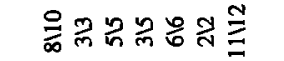 & m \\
\hline 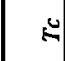 & a & $4=$ & 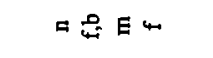 & 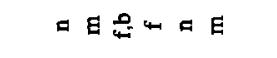 & $-54=5$ & \\
\hline मี & 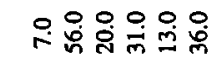 & : & 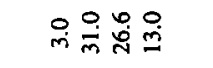 & 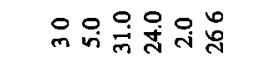 & 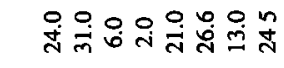 & \\
\hline 悹 & 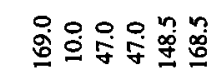 & 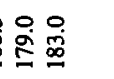 & 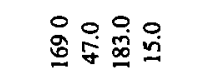 & 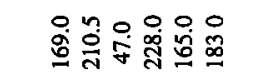 & 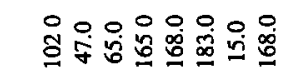 & \\
\hline 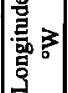 & 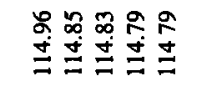 & 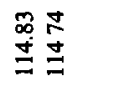 & 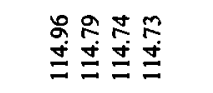 & 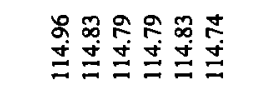 & 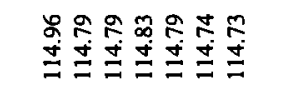 & \\
\hline $\mathrm{z}$ & 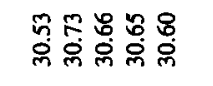 & 萑 & 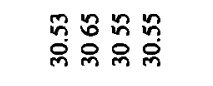 & 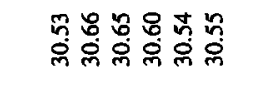 & $\begin{array}{l}\text { ñ } \\
0 \\
0\end{array}$ & \\
\hline 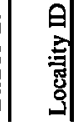 & 些蛋品 & 它喜点 & 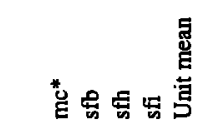 & 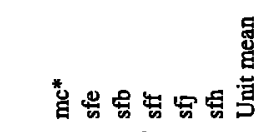 & 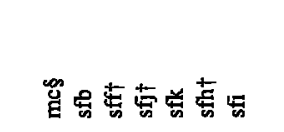 & \\
\hline
\end{tabular}




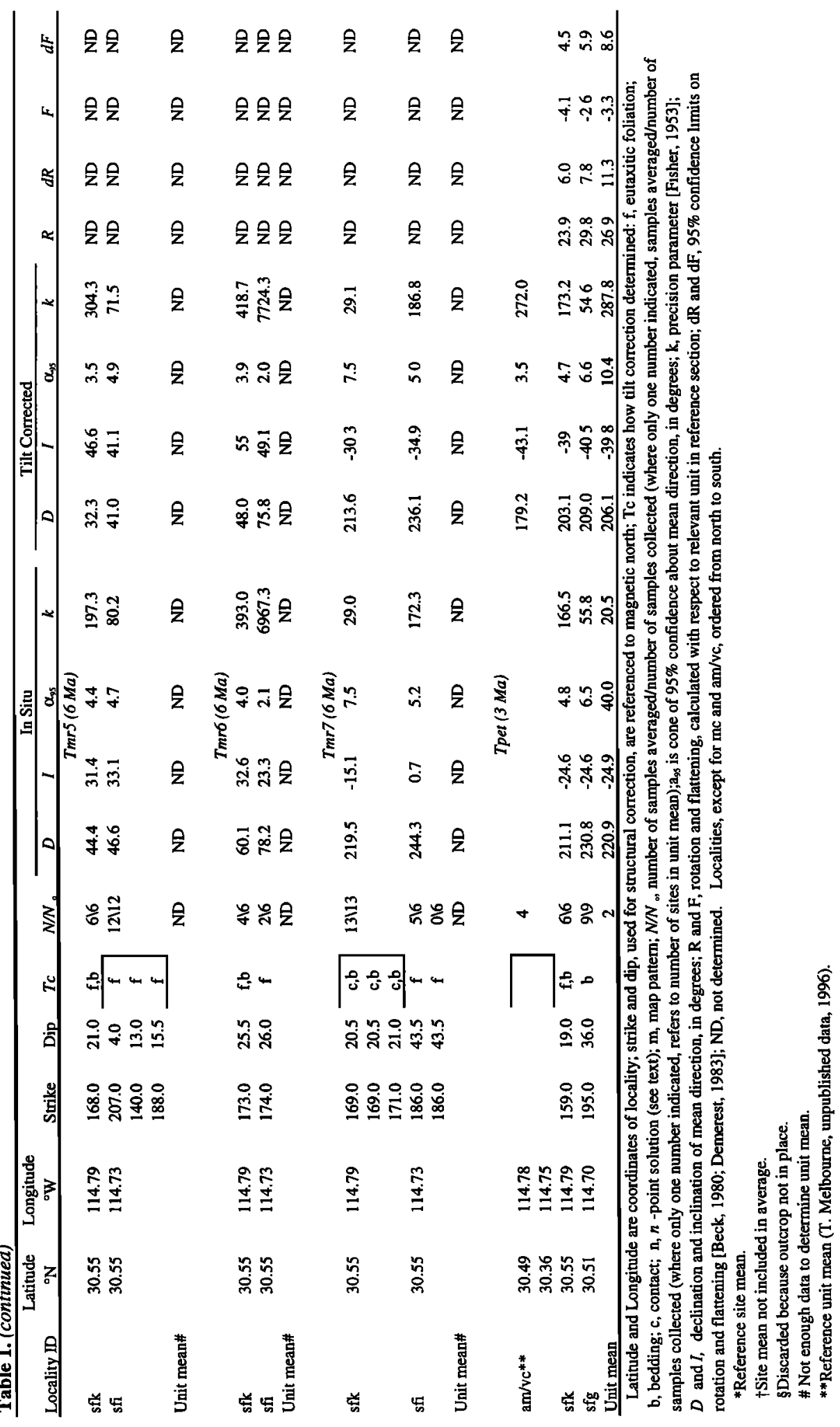


blocks. We conclude, based on available data, that no strong case can be made for relative block rotations in these areas.

We do, however, find an important component of differential rotation between the reference localities and all other localities (Figures 6 and 7, and Table 1). Declinations in 12.5, 6 , and $3 \mathrm{Ma}$ ash flow tuffs from the Sierra San Fermín and Cañon El Parral area are consistently clockwise of declination; in reference sections at Mesa Cuadrada and Arroyo MatomíValle Curbina (Figure 3). Rotations within a single cooling unit are somewhat scattered for $6 \mathrm{Ma} \mathrm{Tmr} 3 \mathrm{a}$ but quite consistent for the tuff of San Felipe and the $6 \mathrm{Ma} T \mathrm{mr} 3 \mathrm{~b}$. Three site means (Tmsf from SFD and SFH and Tmr3b from SFE) show statistically significant inclination anomalies, two of them steeper and one shallower than expected. Possible sources of these anomalies have been discussed above. The anomalies are not systematic, however, and are likely due to errors in tilt corrections.

\subsection{Comparison of Unit Means With Reference Localities}

Because no strong case exists for significant rotation between localities (excluding reference localities), we calculate "regional" unit means by averaging site means from each individual tuff. Averaging in this way incorporates error due to tilt corrections and true spatial variability. We then determine estimates of rotation and flattening for unit means relative to Mesa Cuadrada and Arroyo Matomí-Valle Curbina. The results, with $\alpha_{95}$ uncertainties in Table 1 , indicate no statistically significant inclination anomalies.

The general clockwise deflection of site mean directions from the Sierra San Fermín and part of the Sierra San Felipe, relative to the reference localities, is kinematically compatible with clockwise block rotations in a zone of mapped sinistral faulting. Although our reference localities are located within the deforming plate boundary zone, mapping shows that they lie outside of this region of sinistral faulting [Stock, 1993; Stock et al., 1991]. Paleomagnetic results from areas south of the present study area also suggest that block rotations in the northern Puertecitos Volcanic Province are confined to regions with northeast striking strike-slip faults [Nagy, 1997]. The Sierra Santa Isabel (footwall of Santa Isabel fault; Figure 3), for example, is an area of closely spaced, small offset normal faults and dextral faults in which paleomagnetic directions of 6 $\mathrm{Ma}$ ash flow tuffs are up to $30^{\circ}$ counterclockwise of vectors from the Sierra San Fermín [Nagy, 1997]. It thus appears that Mesa Cuadrada, Sierra Santa Isabel, and Arroyo Matomí may lie outside the zone of late Miocene/Pliocene block rotations.

Because the reference localities (i.e., Mesa Cuadrada and Arroyo Matomí-Valle Curbina) lie within the Gulf Extensional Province, they may have been rotated relative to the undeformed interior part of the peninsula. These reference localities lie in regions of known normal and minor dextral faulting and may have undergone clockwise (or counterclockwise?) rotation themselves. The overall pattern of clockwise deflections argues for significant clockwise rotation of the Sierra San Fermin, but the absolute amounts of rotation cannot be determined from the existing data.

\subsection{Partitioning of Rotation}

Because older ash flow tuffs have undergone more extension than younger tuffs [e.g., Lewis and Stock, 1998], we compare unit means from $12.5 \mathrm{Ma}, 6 \mathrm{Ma}$, and $3 \mathrm{Ma}$ tuffs to determine whether older tuffs have also undergone more rotation than younger tuffs. The average rotation of the $6 \mathrm{Ma} \operatorname{Tmr} 3 \mathrm{~b}\left(29.7^{\circ} \pm\right.$ $\left.14.5^{\circ}\right)$ is defined by a reasonably well-grouped unit mean and is our best estimate of the magnitude of rotation between $6 \mathrm{Ma}$ and the present. Comparison of unit means from the $12.5 \mathrm{Ma}$ tuff of San Felipe and the $6 \mathrm{Ma} T \mathrm{mr} 3 \mathrm{~b}$ indicates a statistically
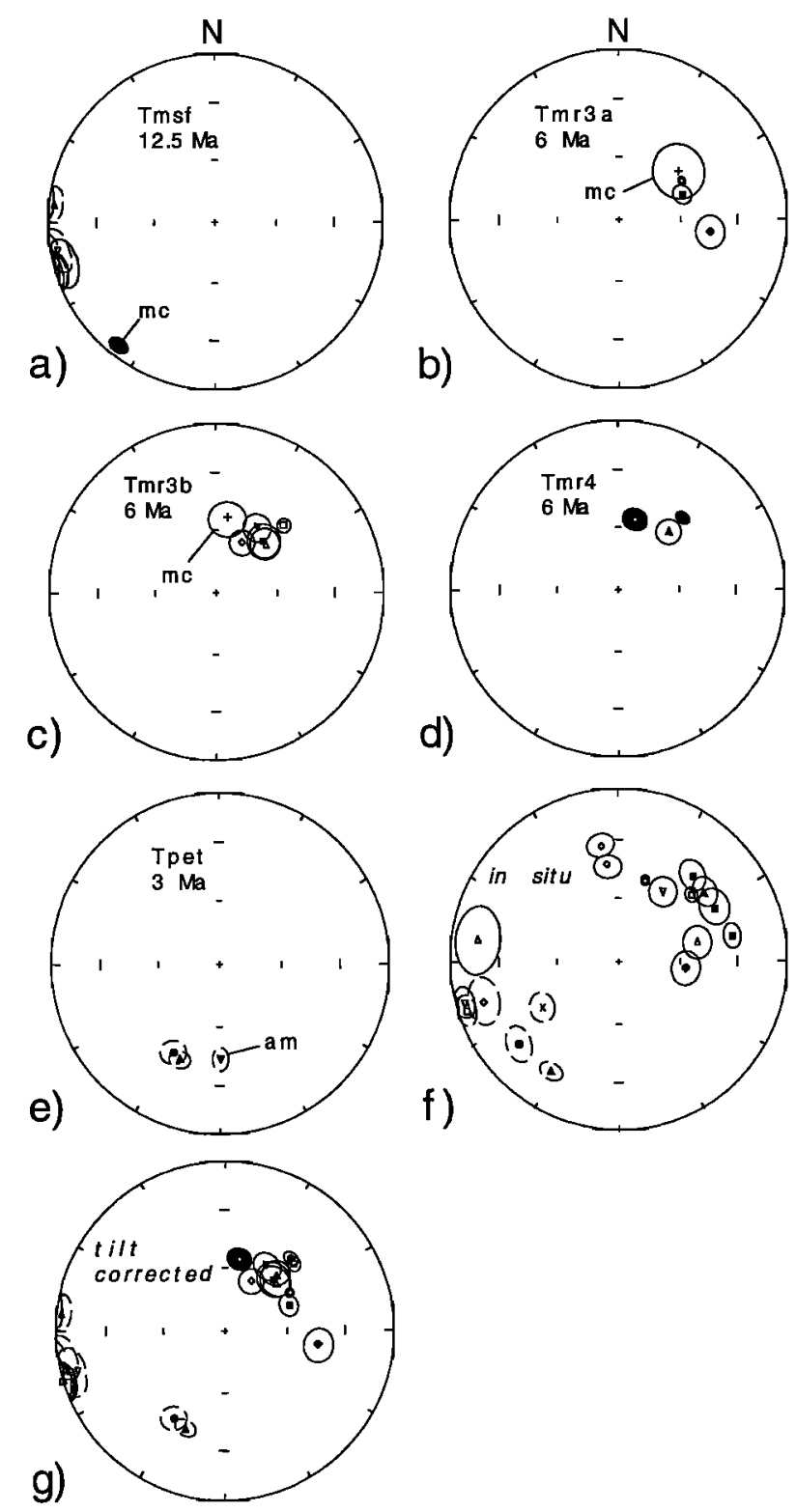

Figure 6. Equal-area projections of structurally corrected site mean directions with projected cones of $95 \%$ confidence grouped by lithologic unit. Solid line (dashed line) ellipses indicate the lower (upper) hemisphere. Symbols: plus, Mesa Cuadrada; cross, SFD; open square, SFE; open diamond, SFB; open triangle, SFF; open inverted triangle, SFJ; solid square, SFH; solid diamond, SFI; solid triangle, SFK; solid circle, SFG; solid inverted triangle, AM/VC. Structural corrections are listed in Table 1. Only least squares line fits with maximum angular deviation (MAD [Kirschvink, 1980]) less than $10^{\circ}$ were used to calculate mean. Local reference vectors for each unit indicated as follows: mc, Mesa Cuadrada; am, Arroyo MatomíValle Curbina. (a) - (e) Site means for principal marker tuffs. (f) - (g) All site means plotted together (including all $6 \mathrm{Ma}$ tuffs in Table 1), in situ and tilt-corrected coordinates, respectively.

insignificant $11^{\circ} \pm 17^{\circ}$ of clockwise rotation between about 12.5 and $6 \mathrm{Ma}$. All the rotation thus seems to have occurred since about $6 \mathrm{Ma}$. Assuming a constant rate of rotation, the Sierra San Fermín-Cañon El Parral area has rotated some $5^{\circ} \pm$ $3 \%$ Myr with respect to Mesa Cuadrada since $6 \mathrm{Ma}$. 


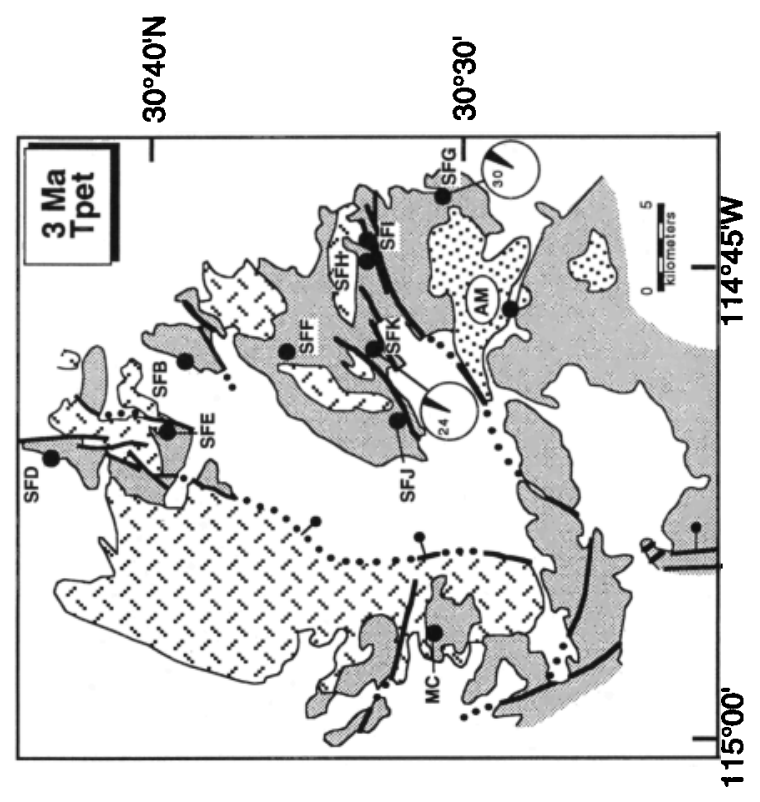

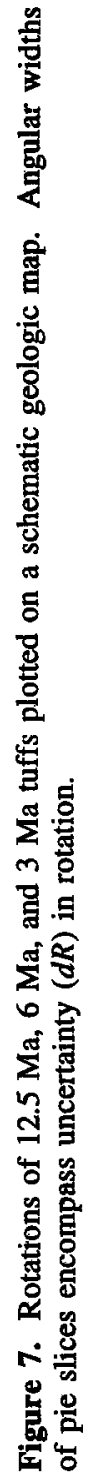
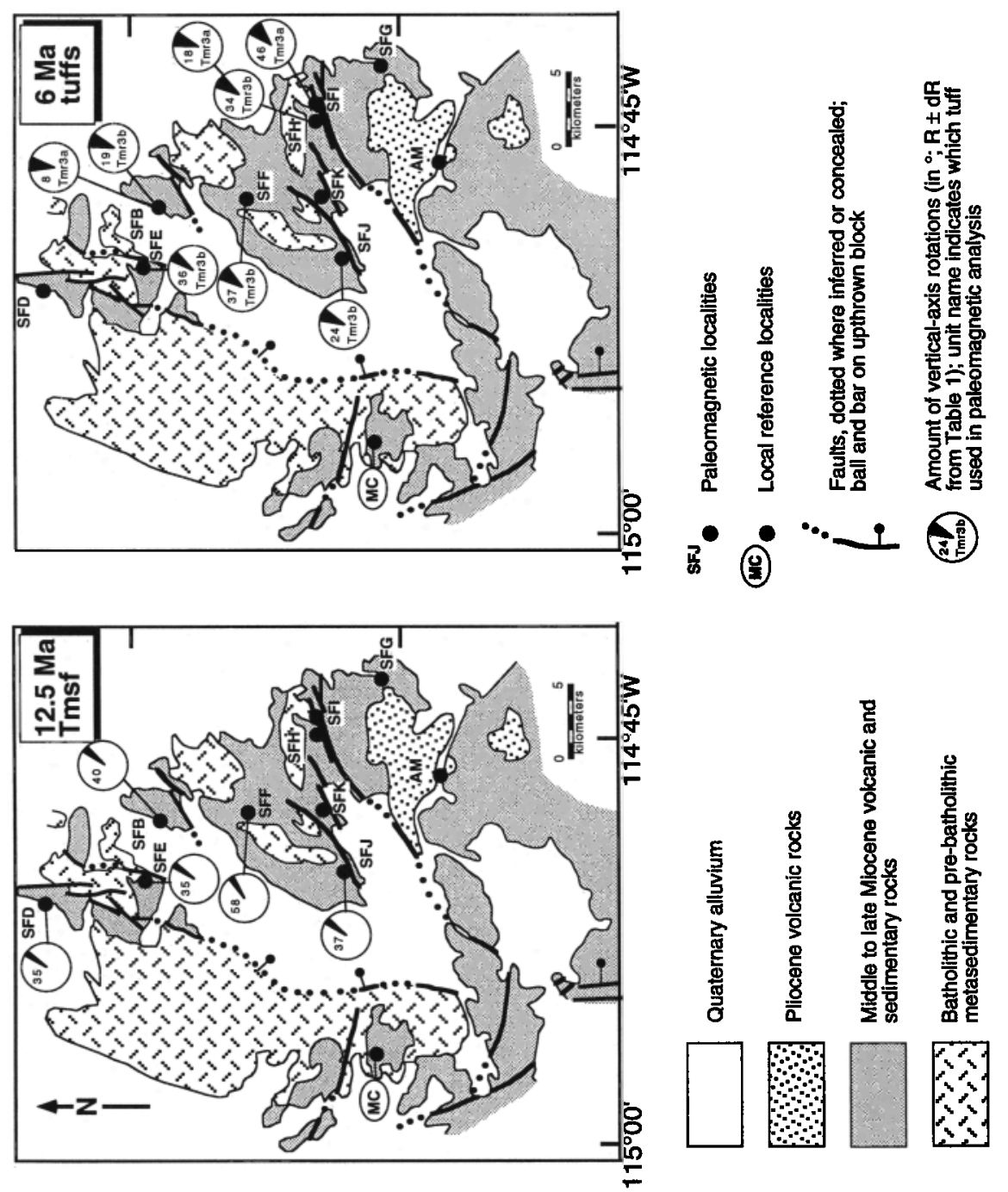
We lack sufficient control on relative rotations between sections with $6 \mathrm{Ma}$ tuffs and sections with $3 \mathrm{Ma}$ tuffs to draw definitive conclusions about partitioning of rotation in the intervals 6 to $3 \mathrm{Ma}$ and 3 to $0 \mathrm{Ma}$. However, rotation of $3 \mathrm{Ma}$ Tpet, relative to reference locality Arroyo Matomi-Valle Curbina $\left(26.9^{\circ} \pm 11.3^{\circ}\right)$, is the same as the average rotation for the $6 \mathrm{Ma} \mathrm{Tmr} 3 \mathrm{~b}$ at locality SFK relative to reference locality Mesa Cuadrada. All of the relative rotation in the area therefore could have occurred within the last $3 \mathrm{Myr}$. Structural relations suggest, however, that the initiation of vertical axis block rotations corresponds to clockwise rotation consistent with Pacific-North America relative displacement [Stock and Hodges, 1989; Lewis and Stock, 1998], profuse rhyolitic volcanism [e.g., Martín-Barajas et al., 1995; Lewis, 1996], and an increase in the rate of extension [Lewis and Stock, 1998], all of which occurred at about $6 \mathrm{Ma}$. Although significant sinistral faulting on NE striking planes did not begin until late Pliocene time [Lewis and Stock, 1998], older fault planes may have accommodated oblique slip and block rotation between 6 and 3 Ma. Additional paleomagnetic and structural data are needed to further evaluate partitioning of rotation. We conclude that relative rotations began after about $6 \mathrm{Ma}$.

Clockwise rotations of $30^{\circ}$ were previously inferred from a study of upper Miocene(?)-Pliocene intertidal mudstones from northeastern Baja California [Strangway et al., 1971]. Three of the localities from that study lie near the eastern end of the El Coloradito fault zone (Figure 3). Reworked tuffs in the El Coloradito marine section are related to the $3 \mathrm{Ma}$ Tuffs of Mesa El Tábano sequence [Martín-Barajas et al., 1995, 1997].

We calculate a field direction from the three Strangway et al. [1971] locality means from El Coloradito (Figure 3), excluding one locality which is $200 \mathrm{~km}$ from our study area (Cañon Rojo on the west side of the Cucapah Mountains). The resultant field direction $\left(D=44^{\circ}, I=43^{\circ}, \alpha_{95}=15^{\circ}, k=49\right)$ corresponds to a pole at $51.0^{\circ} \mathrm{N}, 158.4^{\circ} \mathrm{W}, \mathrm{d} p=11.5^{\circ}, \mathrm{d} m=18.6^{\circ}$. This corresponds to $46^{\circ} \pm 16^{\circ}$ of clockwise rotation compared to the expected direction $\left(D=358^{\circ}, I=48^{\circ}, \alpha_{95}=3^{\circ}\right)$, calculated from the Irving and Irving [1982] $10 \mathrm{Ma}$ pole for stable North America $\left(88^{\circ} \mathrm{N}\right.$, $101^{\circ} \mathrm{E}, \alpha_{95}=3^{\circ}$ ). Although subsequent work suggested that the original magnetization directions of these muds may have been overprinted by a chemical remanent magnetization [Larson and Walker, 1975], we speculate, by comparison with our results from the adjacent Sierra San Fermin and the occurrence of numerous sinistral faults in the El Coloradito area, that the apparent clockwise rotation found by Strangway et al. [1971] may be real.

Recent paleomagnetic work at El Coloradito and nearby Playa Cristina indicates about $15^{\circ}$ clockwise vertical axis rotation with respect to poles for stable Baja California and stable North America [Rebolledo Vieyra, 1994, also written communication, 1996]. This amount overlaps, within uncertainties, the values for the 6 and $3 \mathrm{Ma}$ rocks obtained in the present study. A new ${ }^{40} \mathrm{Ar} /{ }^{39} \mathrm{Ar}$ date of $2.50 \pm 0.05 \mathrm{Ma}$ on a tephra bed within the El Coloradito and Playa Cristina marine sections [J. M. Stock, unpublished data, 1994] and stratigraphic correlations with other dated sections [Martín-Barajas et al., 1995, 1997] show that the section sampled by Rebolledo Vieyra is younger than $3.27 \pm 0.04 \mathrm{Ma}$. The measured rotations have occurred, therefore, in the last $\sim 3 \mathrm{Myr}$, suggesting rates of about $5 \% \mathrm{Myr}$, consistent with results reported here.

\section{Evaluation of Block Rotation Model}

Declination discordances in northeastern Baja Calıfornia indicate substantial vertical axis block rotations. Because north striking normal, NE striking sinistral oblique, and NE to ENE striking sinistral strike-slip faults typify the structure of the study area, and much of the rest of northeastern Baja
California, we propose that clockwise block rotations are due to oblique divergence in the deforming zone between the Pacific and North American plates.

Although the boundaries of the rotated area in northeastern Baja California have not been delimited by paleomagnetic work, they can be inferred from the structural geometry of the area (Figure 8). The western boundary is likely to be the NNW striking $\left(\sim 340^{\circ}\right)$, dextral oblique Valle de San Felipe fault system, postulated to be a continuous structure parallel to, but east of, the San Pedro Mártir fault. Alternatively, the boundary could be the San Pedro Mártir fault itself. The Valle de San Felipe fault and the dip-slip San Pedro Mártir fault bound a basin in which sinistral faulting has not been identified. These faults appear to form the western boundary of the region of northeast striking faults at least as far north as the dextral strike-slip Agua Blanca fault (Figure 2). The eastern boundary of the zone of rotations may be another (unidentified) oblique dextral fault east of the Sierra San Fermín, perhaps associated with transform faulting in the gulf.

The northern and southern ends of the rotating zone most likely correspond to two west-northwest-striking accommodation zones, the Sierra Las Tinajas and Matomi accommodation zones, active since middle to late Miocene time [Stock and Hodges, 1990; Axen, 1995; Lee et al., 1996]. These two zones have similar strikes (Figures 1 and 8 ). The rotating zone thus can be approximated as a parallelogram with rotations dying out abruptly to the south and, speculatively, to the north. Mesa Cuadrada, Sierra Santa Isabel, and Arroyo Matomí are located within, or adjacent to, the southern accommodation zone. Blocks within this zone appear to have rotated relatively less than those in the Sierra San Fermín, and may not have been rotated at all [Nagy, 1997]. A northwest-striking dextral shear zone in the southern Sierra San Felipe may connect the Valle de San Felipe and Sierra San Felipe faults [Stock and Hodges, 1990], isolating Mesa Cuadrada from the zone of rotations.

The shape of the zone of rotated blocks, the association between sinistral slip and normal faulting, and the apparent uniform sense and relatively uniform amount of block rotation favor application of a uniform-sense block rotation model applicable to obliquely divergent crustal deformation (Figure 8) [McKenzie and Jackson, 1986; Nur et al., 1986; Lamb, 1987, 1994]. Our block model explains extension without block rotation in Valle de San Felipe and some distributed dextral shear within the accommodation zones (Figure 8). Blocks that terminate against the west and east boundaries of the model are pinned, whereas blocks terminating against an accommodation zone are not pinned. In the latter case, pinning the blocks produces a decreasing magnitude of rotation toward the accommodation zones and triangular-shaped extensional basins between blocks, contrary to our observations. Field relations are consistent with distributed dextral shear in the two accommodation zones [e.g., Lee et al., 1996; Stock and Hodges, 1990].

In applying the oblique divergence model, the Valle de San Felipe-Valle Chico is extended parallel to the trend of the southern accommodation zone, while the region east of the Valle de San Felipe fault is sheared until blocks rotated the paleomagnetically observed $30^{\circ} \pm 15^{\circ}$. The model predicts dextral shear parallel to the Valle de San Felipe fault and ENE directed extension. Segments of the Valle de San Felipe fault are known to accommodate dextral slip [Grover et al., 1993]. The direction of extension agrees with estimates made from field relations [Stock and Hodges, 1990] and from inversion of kinematic data [Lewis, 1994; Lewis and Stock, 1998]. The scaled block model predicts that within the zone of rotations, $\sim 23 \mathrm{~km}$ of shear (NNW directed) and $7 \mathrm{~km}$ of extension $(20 \%$, ENE directed) have occurred. This amount of extension is consistent with some of the highest values computed from palinspastic reconstructions [Stock and Hodges, 1990; Lewis 


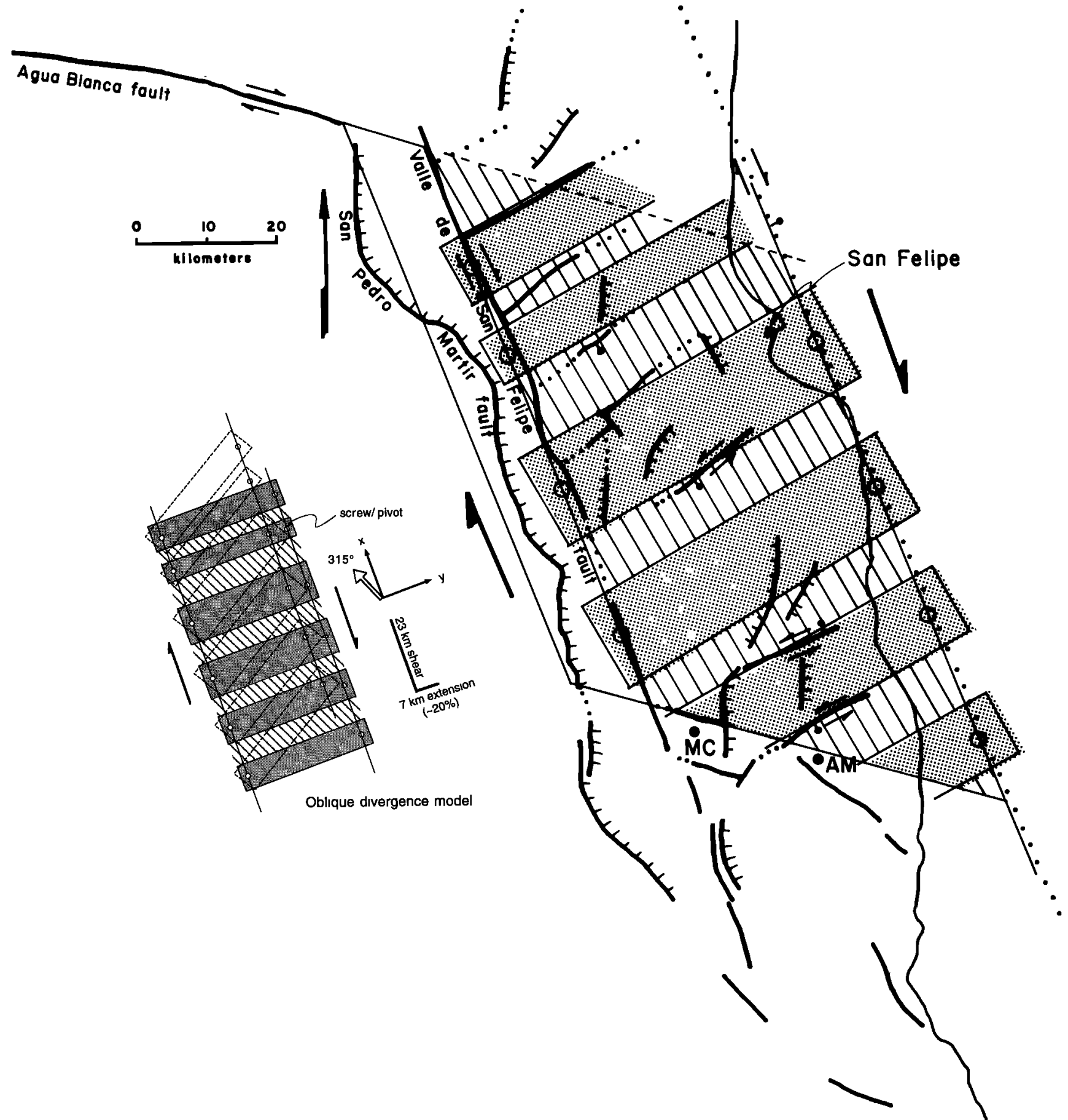

Figure 8. Oblique divergence block model for observed crustal rotation in northeastern Baja California. The model is drawn such that the boundaries of the deforming zone are aligned with the average strike of the San Pedro Mártir fault $\left(\sim 340^{\circ}\right)$, the principal fault of the Main Gulf Escarpment at this latitude, and the Valle de San Felipe fault, the proposed western boundary of vertical axis rotations. Ruled zones comprise area created by divergence (extensional basins).

and Stock, 1998] and is well within the range of possible values estimated for this area [Stock and Hodges, 1989]. The amount of shear resolved in the direction of relative plate motion $\left(\sim 315^{\circ}\right)$ is $\sim 21 \mathrm{~km}$. We emphasize that this is shear and extension in the zone east of the Valle de San Felipe fault and does not include extension on the San Pedro Mártir fault.

\section{Discussion}

The relative amounts of extension and shear in the study area appear to vary with the acute angle between the rift trend and the azimuth of plate motion along the plate margins, in support of experimental models of oblique rifting [e.g., Withjack and Jamison, 1986; Tron and Brun, 1991]. When the Main Gulf Escarpment in northeastern Baja California began forming about $12.5 \mathrm{Ma}$, its north-northwest strike formed an angle of $\sim 30-50^{\circ}$ to the direction of relative plate motion $\left(298^{\circ}\right.$ $\pm 12^{\circ}$ [Stock and Hodges, 1989]). During this early stage of rifting in late Miocene time, normal faults were common and dominated the topography. Oblique sinistral slip and vertical axis block rotations may have begun in latest Miocene to 
Pliocene time as the direction of relative Pacific-North America plate motion rotated clockwise to the modern direction of $315^{\circ}$ $\pm 2^{\circ}$ [Minster and Jordan, 1978; DeMets et al., 1990], and the modern San Andreas fault began to link with the developing system of transform faults and spreading ridges in the mouth of the gulf. This change in the direction of relative plate motion should have been well underway by $\sim 5 \mathrm{Ma}$ to $-3 \mathrm{Ma}$, since these are the time intervals over which the "modern" plate motions are averaged [Minster and Jordan, 1978]. The greater component of dextral shear produced by a smaller angle between the rift trend and azimuth of plate motion has been accommodated in Pliocene to Recent time by kinematically linked normal and sinistral faults and vertical axis rotations. Local vertical axis block rotations, and the geometry of faulting, in northeastern Baja California appear to be part of the kinematic response of a Baja California microplate caught in the boundary zone between the Pacific and North American plates.

Two dynamic models can explain the rotations of paleomagnetic declinations in the study area. In both models, horizontal extension is accommodated by clockwise rotation and combined normal and strike-slip faulting (distributed dextral shear) rather than pure dip-slip movement. Our data cannot resolve which is the best model, but we think it useful to discuss their implications and predictions.

In the first model, distributed dextral shear may have initiated due to subhorizontal basal shear caused by microplate capture [Nicholson et al., 1994]. The initiation of late Miocene oblique rifting in northeastern Baja California may be analogous to the structural transformation that occurred in southern California about $20 \mathrm{Ma}$, as subduction ceased beneath the California margin [Nicholson et al., 1994; Bohannon and Parsons, 1995]. In similar fashion, the east dipping former subduction interface beneath Baja California may have localized extensional detachments. Distributed basal shear resulting from incomplete microplate capture may have initiated clockwise block rotations in northeastern Baja California. Extension and block rotations appear active today, suggesting that northeastern Baja California may not be completely attached to the Pacific plate even now.

In the second model, distributed dextral shear may be related to a deep, vertical shear zone connecting gulf transform faults to major transpeninsular faults. Geophysical and geologic information suggests considerable shear west of the San Andreas fault in late Miocene to Recent time [Yeats, 1983; Hornafius et al., 1986; Luyendyk, 1990; Humphreys and Weldon, 1991]. The San Andreas fault itself has carried only $\sim 2 / 3$ of the relative plate displacement for the last 4-5 Myr and possibly longer [Weldon, 1986].

In either case, distributed dextral shear in northeastern Baja California, accommodated by normal and sinistral faults and vertical axis block rotations, may provide the kinematic connection between the gulf transform faults and faults within the Continental Borderland [Allen et al., 1960; Rockwell et al., 1987; Frez and Gonzalez, 1991; Humphreys and Weldon, 1991; Grover et al., 1993]. This shear may represent an important addition to the $300 \mathrm{~km}$ of relative, Pacific-North America plate displacement computed from cross-gulf geological tie points.

\section{Conclusions}

Our paleomagnetic results from the Sierra San Fermín-Sierra San Felipe demonstrate that the area was affected by differential rotation in late Miocene to younger time. Declinations in $12.5,6$, and $3 \mathrm{Ma}$ ash flow tuffs are clockwise to declinations in reference sections at Mesa Cuadrada and Arroyo MatomíValle Curbina. Rotations in the Sierra San Fermín-Sierra San Felipe study area occurred primarily on north striking normal faults and northeast to east-northeast striking sinistral faults, many of which may be reactivated, late Miocene normal faults. Field relations elsewhere suggest that Tertiary rocks throughout the Gulf Extensional Province in northeastern Baja California may be deformed similarly and may have undergone clockwise rotations as well.

Relative declination discordances in $6 \mathrm{Ma}$ ash flow tuffs indicate a net clockwise rotation of $30^{\circ} \pm 15^{\circ}$. Clockwise rotation between 12.5 and $6 \mathrm{Ma}$ is statistically insignificant $\left(11^{\circ} \pm\right.$ $\left.17^{\circ}\right)$. Structural and timing constraints suggest that rotations in this area began post- $6 \mathrm{Ma}$. Structural observations also suggest that the uniform-sense block rotation model may apply to the basins and ranges east of the Valle de San Felipe fault but that rotations may be smaller or absent from the Valle de San Felipe fault westward to the Main Gulf Escarpment. Oblique sinistral slip and vertical axis block rotations may have begun in late Miocene time as the direction of relative plate motion rotated clockwise and the modern San Andreas fault began to link with the developing system of transform faults and spreading ridges in the mouth of the gulf. Shear increased in late Pliocene time, producing kinematically linked normal and sinistral faults and continued vertical axis rotations, as the gulf became the principal locus of Pacific-North America relative motion.

We favor a model in which nonrigid behavior, including significant local rotations, is part of the kinematic response of a Baja California microplate caught in the boundary zone between the Pacific and North American plates. Two dynamic models may explain this shear. In one, rotation accumulated above a deep, subhorizontal, basal shear zone. Rotating blocks may extend downwards to a detachment beneath the extensional province, either a low-angle eastward continuation of the San Pedro Mártir fault or a basal shear surface on the former top of the subducted plate. In the other model, distributed dextral shear occurred above a deep vertical shear zone connecting transform faults in the northern gulf with dextral transpeninsular faults. In either case, shear may have transferred onto faults west of the San Andreas fault, contributing to late Miocene to Recent clockwise rotation of the Western Transverse Ranges.

Acknowledgments. This research was partially supported by a National Science Foundation grant (EAR-92-18381) and a Presidential Young Investigator Award (EAR-92-96102) to Joann M. Stock. Additional support was provided by the Harvard University Department of Earth and Planetary Sciences Grants-in-Aid for Fieldwork. We thank Joe Kirschvink for the use of his paleomagnetics laboratory and sampling equipment, John Holt for patient guidance in the field and the lab, and the Division of Geological and Planetary Sciences at the California Institute of Technology for many resources necessary for completion of this project. We are grateful to Mario Rebolledo Vieyra and Liz Warner Holt for assistance in the field and to John Holt, Tim Melbourne, Elizabeth Nagy, and Leslie Sonder for many helpful discussions. Revisions were done at the Universitat de Barcelona, funded in part by a
Fulbright Fellowship to Lewis. We thank John Geissman, Jonathan Hagstrum, Mark Hudson, Bruce Luyendyk, Steve Sheriff, and Paul Umhoefer for careful reviews This is California Institute of Technology Division of Geological and Planetary Sciences contribution 5615.

\section{References}

Allen, C. R., L. T. Silver, and F. G. Stehli, Agua Blanca fault--A major transverse structure of northern Baja California, Mexico, Geol. Soc. Am. Bull., 71, 457-482, 1960.

Andersen, R. L., Geology of the Playa San Felipe quadrangle, Baja California, Mexico, M.S. thesis, 214 pp., San Diego State University, San Diego, Calif., 1973.

Axen, G., Extensional segmentation of the Main Gulf Escarpment, Mexico and United States, Geology, 23, 515-518, 1995.

Beck, M. E., Paleomagnetic record of plate-margin tectonic processes along the western edge of North America, J. Geophys. Res., 85, 7115-7131, 1980.

Best, M. G., R. T. Shuey, C. R. Caskey, and S. K. Grant, Stratigraphic relations of members of the Needles Range Formation at type localities in southwestern Utah, Geol. Soc. Am. Bull., 84, 3269-3278, 1973. 
Boehm, M., An overview of the lithostratigraphy, biostratigraphy, and paleoenvironments of the late Neogene San Felipe marine sequence, Baja California, Mexico, in Geology of the Baja California Peninsula, Publ. 39, edited by V. A. Frizzell, pp. 253-266, Soc. for Sediment. Geol., Pac. Section, Los Angeles, Calif., 1984.

Bogen, N. L., and L. Seeber, Neotectonics of rotating blocks within the San Jacinto fault zone, southern California, Eos Trans. $A G U, 67$, $1200,1986$.

Bohannon, R. G., and T. Parsons, Tectonic implications of post-30 Ma Pacific and North American relative plate motions, Geol. Soc. Am. Bull., 107, 937-959, 1995.

Brown, L. G., Recent fault scarps along the eastern escarpment of the Sierra San Pedro Mártir, Baja California, M.S. thesis, 108 pp., San Diego State Univ., San Diego, Calif., 1978.

Bryant, B. A., Geology of the Sierra Santa Rosa basin, Baja California, Mexico, M.S. thesis, 75 pp., San Diego State Univ., San Diego, Calif., 1986.

Burbank, D. W., and D. P. Whistler, Temporally constrained tectonic rotations derived from magnetostratigraphic data: Implications for the initiation of the Garlock fault, California, Geology, 15, 1172-1175, 1987.

Byrd, J. O. D., R. B. Smith, and J. W. Geissman, The Teton fault, Wyoming: Topographic signature, neotectonics, and mechanisms of deformation, J. Geophys. Res., 99, 20,095-20,122, 1994.

Chan, L. S., Apparent tectonic rotations, declination anomaly equations, and declination anomaly charts, J. Geophys. Res., 93, 12,151-12,158, 1988.

Demarest, H. H., Jr., Error analysis for the determination of tectonic rotation from paleomagnetic data, J. Geophys. Res., 88, 4321-4328, 1983.

DeMets, C., R. G. Gordon, D. F. Argus, and S. Stein, Current plate motions, Geophys. J. Int., 101, 425-478, 1990.

Dickinson, W. R., Kinematics of transrotational tectonism in the California Transverse Ranges and its contribution to cumulative slip along the San Andreas transform fault system, Spec. Pap. Geol. Soc. Am., 303, 46 pp., 1996.

Dokka, R. K., and R. H. Merriam, Late Cenozoic extension of northeastem Baja California, Geol. Soc. Am. Bull., 93, 371-378, 1982.

Fenby, S. S., and R. G. Gastil, Geologic-tectonic map of the Gulf of California and surrounding areas, in The Gulf and Peninsular Province of the Californias, edited by J. P. Dauphin and B. R. T. Simoneit, AAPG Mem., 47, 79-83, 1991.

Fisher, R. A., Dispersion on a sphere, Proc. R. Soc. London, Ser. A, 217, 295-305, 1953

Frez, J., and J. J. Gonzalez, Crustal structure and seismotectonics of northern Baja California, in The Gulf and Peninsular Province of the Californias, edited by J. P. Dauphin and B. R. T. Simoneit, AAPG Mem., 47, 261-283, 1991.

Gastil, R. G., and D. Krummenacher, Reconnaissance geology of coastal Sonora between Puerto Lobos and Bahía Kino, Geol. Soc. Am. Bull., 88, 189-198, 1977.

Gastil, R. G., D. Lemone, and W. Stewart, Permian fusilinids from near San Felipe, Baja California, Am. Assoc. Pet. Geol. Bull., 57, 746-747, 1973.

Gastil, R. G., R. P. Phillips, and E. C. Allison, Reconnaissance geology of the state of Baja California, Mem. Geol. Soc. Am., 140, 170 pp., 1975.

Gromme, C. S., E. H. McKee, and M. C. Blake, Paleomagnetic correlations and potassium-argon dating of middle Tertiary ash flow sheets in eastern Great Basin, Nevada and Utah, Geol. Soc. Am. Bull., 83, $1619-1638,1972$.

Grover, T. M., R. Heath, C. Walls, M. M. Miller, and C. M. Rubin, Evidence for active faulting in Valle de San Felipe, northern Baja California, Mexico: Space-based observations of the transition from an oceanic to continental transform boundary, Geol. Soc. Am. Abstr. Programs, 25, A-481, 1993.

Hagstrum, J. T., M. G. Sawlan, B. P. Hausback, J. G. Smith, and C. S. Gromme, Miocene paleomagnetism and tectonic setting of the Baja California peninsula, Mexico, J. Geophys. Res., 92, 2627-2639, 1987.

Hamilton, W., Recognition on space photographs of structural elements of Baja California, U.S. Geol. Surv. Prof. Pap., 718, 26 pp., 1971.

Hausback, B. P., Miocene paleomagnetism of Baja California Sur: Evidence concerning the structural development of western Mexico, Geofis. Int., 27, 463-483, 1988

Hornafius, J. S., B. P. Luyendyk, R. R. Terres, and M. J. Kamerling, Timing and extent of Neogene tectonic rotation in the western Transverse Ranges, California, Geol. Soc. Am. Bull., 97, 1476-1487, 1986.

Hudson, M. R., and J. W. Geissman, Paleomagnetic and structural evidence for middle Tertiary counterclockwise block rotation in the Dixie Valley region, west-central Nevada, Geology, 15, 638-642, 1987

Hudson, M. R., D. A. Sawyer, and R. G. Warren, Paleomagnetism and rotation constraints for the middle Miocene southwestern Nevada volcanic field, Tectonics, 13, 258-277, 1994

Humphreys, E. D., and R. J. Weldon II, Kinematic constraints on the rifting of Baja California, in The Gulf and Peninsular Province of the Californias, edited by J. P. Dauphin and B. R. T. Simoneit, $A A P G$ Mem., 47, 217-229, 1991

Irving, E., and G. A. Irving, Apparent polar wander paths Carboniferous through Cenozoic and the assembly of Gondwana, Geophys. Surv., 5 141-188, 1982.

Johnson, N. M., C. B. Officer, N. D. Opdyke, G. D. Woodward, P. K. Zeitler, and E. H. Lindsay, Rates of late Cenozoic tectonism in the Vallecito-Fish Creek basin, western Imperial Valley, California, Geology, $I 1,664-667,1983$.

Kamerling, M. J., and B. P. Luyendyk, Paleomagnetism and Neogene tectonics of the northern Channel Islands, California, J. Geophys. Res., 90, 12,485-12,502, 1985.

Kirschvink, J. L., The least-squares line and plane and the analysis of paleomagnetic data, Geophys. J. R. Astron. Soc., 62, 699-718, 1980.

Kissel, C. C. Laj, A Mazaud A. Poisson, Y Savascin, K. Simeakis, C Fraissinet, and J. L. Mercier, Paleomagnetic study of the Neogene formations of the Aegean area, in Tectonic Evolution of the Tethyan Region, edited by A. M. C Sengor et al., NATO ASI, Ser. C, 259, 137 $157,1989$.

Lamb, S. H., A model for tectonic rotations about a vertical axis, Earth Planet. Sci. Lett., 84, 75-86, 1987.

Lamb, S. H., Behavior of the brittle crust in wide plate boundary zones, J. Geophys.Res., 99, 4457-4483, 1994.

Larson, E. E., and T. R. Walker, Development of chemical remanent magnetization during early stages of red-bed formation in late Cenozoic sediments, Geol. Soc. Am. Bull., 86, 639-650, 1975.

Lee, J., M. M. Miller, R. Crippen, B. Hacker, and J. Ledesma Vazquez, Middle Miocene extension in the Gulf Extensional Province, Baja California: Evidence from the southern Sierra Juarez, Geol. Soc. Am. Bull., J08, 505-525, 1996.

Lewis, C. J., Constraints on extension and strike-slip in the Gulf of California Extensional Province from the Sierra San Fermin, northeastern Baja California, Mexico, Ph.D. thesis, 361 pp., Harvard Univ., Cambridge, Mass., 1994.

Lewis, C. J., Stratıgraphy and geochronology of Miocene and Pliocene volcanic and marine rocks in the Sierra San Fermín and southern Sierra San Felipe, Baja California, Mexico, Geofís. Int., 35, 3-25, 1996.

Lewis, C. J., and J. M. Stock, Structural accommodation of Neogene ex tension and dextral shear in the Sierra San Fermín, northeastern Baja California, Mexico, J. Struct. Geol., 1998, in press.

Luyendyk, B. P., Neogene-age fault slip in the continental transform zone in southern California, Ann. Tectonicae, 4, 24-34, 1990.

Luyendyk, B. P., A model for Neogene crustal rotations, transtension, and transpression in southern California, Geol. Soc. Am. Bull., 103, 1528-1536, 1991

Luyendyk, B P., M. J. Kamerling, R. R. Terres, and J. S. Hornafius, Simple shear of southern California during Neogene time suggested by paleomagnetic declinations, J. Geophys. Res., 90, 12,454-12,466, 1985

MacFadden, B. J., C. C. Swisher III, N. D. Opdyke, and M. O. Woodburne, Paleomagnetism, geochronology, and possible tectonic rotation of the middle Miocene Barstow Formation, Mojave Desert, southern California, Geol. Soc. Am. Bull., 102, 478-493, 1990.

Martín-Barajas, A., and J. M. Stock, Estratigrafía y petrología de la secuencia volcánica de Puertecitos, noreste de Baja California. Transición de un arco volcánico a rift, in Contribuciones a la Tectónica del Occidente de México, Monogr., no. 1, edited by L. A. Delgado Argote and A. Martín-Barajas, pp. 66-89, Union Geofís. Mex., Ensenada, Baja California, 1993

Martín-Barajas, A., J. M. Stock, P. Layer, B. Hausback, P. Renne, and M. Lopez-Martínez, Arc-rift transition volcanism in the Puertecitos volcanic province, northeastern Baja California, Mexico, Geol. Soc. Am. Bull., 4, 407-424, 1995.

Martín-Barajas, A., M. Téllez-Duarte, and J. M. Stock, The Puertecitos Formation: Pliocene sedimentation along an accommodation zone in northeastern Baja California, in Pliocene Carbonate and Related Facies Flanking the Gulf of California, Baja California, Mexico, edited by M. E. Johnson and J. Ledesma-Vázquez, Spec. Pap. Geol. Soc. Am., 318, 1-24, 1997.

McDonald, W. D., Net tectonic rotation, apparent tectonic rotation, and the structural tilt correction in paleomagnetic studies, J. Geophys. Res., 85, 3659-3669, 1980.

McIntosh, W. C., Evaluation of paleomagnetism as a correlation criterion for Mogollon-Datil ignimbrites, southwestern New Mexico, $J$. Geophys. Res., 96, 13,459-13,483, 1991.

McKenzie, D., and J. Jackson, The relationship between strain rates, crustal thickening, paleomagnetısm, finite strain and fault movements within a deforming zone, Earth Planet. Sci. Lett., 65, 182-202, 1983.

McKenzie, D., and J. Jackson, A block model of distributed deformation by faulting, J. Geol. Soc. London, 143, 349-353, 1986.

Meisling, K. E., and R. J. Weldon, The late-Cenozoic tectonics of the northwestern San Bernardino Mountains, southern Calıfornı, Geol. Soc. Am. Bull., 101, 106-128, 1989. 
Melbourne, T., J. Holt, and J. M. Stock, Paleomagnetic investigation of the Puertecitos Volcanic Region, B. C., paper presented at International Meeting on Geology of the Baja California Peninsula, Peninsular Geol. Soc., Ensenada, Mexico, 1993.

Minster, J. B., and T. H. Jordan, Present-day plate motions, J. Geophys. Res., 83, 5331-5354, 1978

Nagy, E. A., Extensional deformation and volcanism within the northern Puertecitos Volcanic Province, Sierra Santa Isabel, Baja California, Mexico, Ph.D. thesis, 363 pp., Calif. Inst. of Technol., Pasadena, 1997.

Ness, G. E., and M. Lyle, A seismo-tectonic map of the gulf and peninsular province of the Californias, in The Gulf and Peninsular Province of the Californias, edited by J. P. Dauphin and B. R. T. Simoneit, AAPG Mem., 47, 71-78, 1991 .

Nicholson, C., C. C. Sorlien, T. Atwater, J. C. Crowell, and B. P. Luyendyk, Microplate capture, rotation of the western Transverse Ranges, and initiation of the San Andreas transform as a low-angle fault system, Geology, 22, 491-495, 1994.

Nur, A., H. Ron, and O. Scotti, Fault mechanics and the kinematics of block rotations, Geology, 14, 746-749, 1986.

Nur, A., H. Ron, and $O$. Scotti, Kinematics and mechanics of tectonic block rotations, in Slow Deformation and Transmission of Stress in the Earth, Geophys. Monogr. Ser., vol. 49, edited by S. C. Cohen and P. Vanicek, pp. 31-46, AGU, Washington, D. C., 1989.

Rebolledo Vieyra, M., Implicaciones tectónicas de la deformación en el Plio-Cuaternario de las terrazas marinas al norte de Puertecitos, NE de Baja California, M.S. thesis, 119 pp., Cent de Invest. Cient. y de Educ. Superior de Ensenada, Ensenada, Mexico, 1994.

Reynolds, R. L., Paleomagnetism of welded tuffs of the Yellowstone Group, J. Geophys. Res., 82, 3677-3693, 1977.

Riehle, J. R., Calculated compaction profiles of rhyolitic ash flow tuffs, Geol. Soc. Am. Bull., 84, 2193-2216, 1973.

Rockwell, T. K., and D. L. Lamar, Neotectonics of the Elsinore fault, southern California, in Neotectonics and Faulting in Southern California, Guidebook, pp. 149-208, Geol. Soc. of Am., Boulder, Colo., 1986.

Rockwell, T. K., S. Wilson, M. E. Hatch, G. C. Kennedy, and D. R. Muhs, Ages and deformation of marine terraces in the Agua Blanca fault zone, Baja California, Mexico, Geol. Soc. Am. Abstr. Programs, $19,444,1987$.

Rockwell, T. K., M. E. Hatch, and D. L. Schug, Late Quaternary rates Agua Blanca and borderland faults: Final technical report, contract 14-08-0001-22012, technical report, 122 pp., U. S. Geol. Surv., Reston, Va., 1991

Ron, H., R. Freund, Z. Garfunkel, and A. Nur, Block rotation by strikeslip faulting: Structural and paleomagnetic evidence, $J$. Geophys. Res., 89, 6256-6270, 1984.

Rosenbaum, J. G., Paleomagnetic directional dispersion produced by plastic deformation in a thick Miocene welded tuff, southern Nevada: Implications for welding temperatures, J. Geophys. Res., 91, 12,81712,834, 1986.

Rosenbaum, J. G., Magnetic grain-size variations through an ash flow tuff sheet: Influence on magnetic properties and implications for cooling history, J. Geophys. Res., 98, 11,715-11,727, 1993.

Ross, T. M., B. P. Luyendyk, and R. B. Haston, Paleomagnetic evidence for Neogene clockwise tectonic rotations in the central Mojave Desert, California, Geology, 17, 470-473, 1989.

Slyker, R. G., Geophysical survey and reconnaissance geology of the Valle de San Felipe area, Baja California, Mexico, in Geology of Peninsular California, edited by R. G. Gastil and J. A. Lillegraven, pp. 107-120, Soc. of Sediment. Geol., Tulsa, Oka., 1974.

Stock, J. M., Sequence and geochronology of Miocene rocks adjacent to the Main Gulf Escarpment: Southern Valle Chico, Baja California Norte, Mexico, Geofis. Int., 28-5, 851-896, 1989.
Stock, J. M., Geology of southern Valle Chico and adjacent regions, Baja California, Mexico, Geol. Soc. Am. Map Chart Ser., MCHO76, 1993.

Stock, J. M., and K. V. Hodges, Pre-Pliocene extension around the Gulf of California and the transfer of Baja California to the Pacific plate, Tectonics, 8, 99-115, 1989.

Stock, J. M., and K. V. Hodges, Miocene to Recent structural development of an extensional accommodation zone, northeastern Baja California, Mexico, J. Struct. Geol., I2, 315-328, 1990.

Stock, J. M., A. Martín, F. Suarez, and M. M. Miller, Miocene to Holocene extensional tectonics and volcanic stratigraphy of NE Baja California, Mexico, in Geological Excursions in Southern Californio and Mexico, Guidebook edited by M. J. Walawender and B. B. Hanan, pp. 44-67, Geol. Soc. of Am. Guidebook, Boulder, Colo., 1991.

Stock, J. M., A. Martin-Barajas, and M. Tellez-Duarte, Early rift sedimentation and structure along the NE Margin of Baja California. in Field Conference Guide 1996, edited by P. L. Abbott and J D. Cooper, pp. 337-371, Pacific Section AAPG, Guidebook 73, Bakersfield, Calif., 1996.

Stock, J. M., C. J. Lewis, and E. A. Nagy, The tuff of San Felipe: An extensive middle Miocene pyroclastic flow deposit in NE Baja California, Mexico, paper presented at IAVCEI General Assembly, Int. Assoc. of Volcanol. and Chem. of the Earth Inter., Puerto Vallarta, Mexico, 1997.

Strangway, D. W., B. E. McMahon, T. R. Walker, and E. E. Larson, Anomalous Pliocene paleomagnetic pole positions from Baja California, Earth Planet. Sci. Lett., 13, 161-166, 1971.

Tron, V., and J. P. Brun, Experiments on oblique rifting in brittle-ductile systems. Tectonophysics, 188, 71-84, 1991 .

Walcott, R. I., The kinematics of the plate boundary through New Zealand: A comparison of short and long term deformations, Geophys. J. R. Astron. Soc., 79, 613-633, 1984.

Walcott, R. I., Paleomagnetically observed rotations along the Hikurangi margin of New Zealand, in Paleomagnetic Rotations and Continental Deformation, edited by C. Kissel and C. Laj, pp. 459-471, Kluwer Acad., Norwell, Mass., 1989.

Weiss, S. J., D. C. Noble, and E. H. McKee, Paleomagnetic constraints on the duration of the Pahute Mesa-Trail Ridge eruptive event and associated magmatic evolution, Black Mountain volcanic center, southwestem Nevada, J. Geophys. Res., 94, 6075-6084, 1989.

Weldon, R. J., II, The Late Cenozoic geology of Cajon Pass: Implications for tectonics and sedimentation along the San Andreas fault, Ph.D. thesis, 400 pp., Calif. Inst. of Technol., Pasadena, 1986.

Wells, R. E., and J. W. Hillhouse, Paleomagnetism and tectonic rotation of the lower Miocene Peach Springs Tuff: Colorado Plateau, Arizona, to Barstow, California, Geol. Soc. Am. Bull., 101, 846-863, 1989.

Withjack, M. O., and W. R. Jamison, Deformation produced by oblique rifting, Tectonophysics, I26, 99-124, 1986.

Yeats, R. S., Large scale Quaternary detachments in Ventura Basin, southern Califomia, J. Geophys. Res., 88, 569-583, 1983.

Zijderveld J. D A. AF demagnetization of rocks: Analysis of results, in Methods in Paleomagnetism, edited by K. M. Creer and S. K. Runcorn, pp. 254-286, Elsevier, New York, 1967.

C. J. Lewis, Los Alamos National Laboratory, EES-1, MS D462, Los Alamos , NM 87545. (e-mail: clewis@lanl.gov) J. M. Stock, Seismological Laboratory, California Institute of Technology, MS 252-21, Pasadena, CA 91125. (e-mail: jstock@gps.caltech.edu)

(Received March 10, 1997; revised August 7, 1997; accepted September 18, 1997.) 